\title{
NUTRITIONAL IMPLICATIONS OF RESISTANT STARCH
}

\author{
COMPILED BY N.-G. ASP, J. M. M. VAN AMELSVOORT AND \\ J. G. A. J. HAUTVAST*
}

Applied Nutrition and Food Chemistry, Chemical Center, Lund University, P.O. Box 124, S-221 00 Lund, Sweden (N-GA), Unilever Research Laboratory, P.O. Box 114, 3130 AC Vlaardingen, The Netherlands (JMMvA), and Department of Human Nutrition, Wageningen Agricultural University, Bomenweg 2, 6703 HD Wageningen, The Netherlands (JGAJH) for members* of FLAIR Concerted Action No. 11 (COST 911): Physiological implications of the consumption of resistant starch in man

\section{CONTENTS}

INTRODUCTION AND DEFINITION OF RESISTANT STARCH . . . 2 EVOLUTION OF THE RESISTANT STARCH CONCEPT . . . . . . . . 2 DEFINITION OF RESISTANT STARCH . . . . . . . . . . . . 2

PHYSICAL AND CHEMICAL CHARACTERISTICS AND ANALYSIS OF RESISTANT STARCH .

(Working group I, Chairman M. Champ)

STARCH - THE MOST ABUNDANT COMPONENT OF THE DIET . . . . 4 FACTORS AFFECTING ENZYMIC HYDROLYSIS OF STARCH . . . . . 5 MAIN FORMS OF RESISTANT STARCH . . . . . . . . . . . . . 5 CHARACTERIZATION OF RESISTANT STARCH OBTAINED IN VIVO . . . 6 ANALYSIS METHODS FOR RESISTANT STARCH IN VITRO . . . . . . 8 RESISTANT STARCH INTAKE IN EUROPE . . . . . . . . . . . . . 10 TECHNOLOGY OF RESISTANT STARCH PRODUCTION . . . . . 10

(Working group II, Chairman P. Würsch) FORMATION OF RESISTANT STARCH AT VARIOUS CONDITIONS . . . 10 PRODUCTION OF REFERENCE MATERIALS . . . . . . . . . . . 12

PHYSIOLOGICAL EFFECTS IN THE UPPER GASTROINTESTINAL TRACT

(Working group III A, Chairman E. Gudmand-Hoyer) HYDROGEN AND METHANE BREATH TESTS . . . . . . . . . 13 THE ILEOSTOMY MODEL . . . . . . . . . . . . . . 13 INTUBATION TECHNIQUES . . . . . . . . . . . . . . . . . 14 ANIMAL MODELS . . . . . . . . . . . . . . . . . . . 15

Rat feeding trial . . . . . . . . . . . . . . . . . . . . 18

\footnotetext{
* The participants of the project, called EURESTA, are listed in the Appendix. The review has been organized according to the working group structure of the project. The working group chairmen are given in the contents list.
} 
EFFECTS ON GLYCAEMIC RESPONSE, SATIETY, AND THERMOGENESIS . . 18

EFFECTS ON PLASMA LIPIDS. . . . . . . . . . . . . . . . . . 19

EFFECTS ON MINERAL BALANCE . . . . . . . . . . . . . . . 20

PHYSIOLOGICAL EFFECTS IN THE LARGE BOWEL . . . . . . $\quad 20$

(Working group IIIB, Chairman J. H. Cummings)

FERMENTATION AND RING TEST FOR ITS MEASUREMENT IN VITRO . . 21

ANIMAL MODELS . . . . . . . . . . . . . . . . . . . . 21

CELL PROLIFERATION .

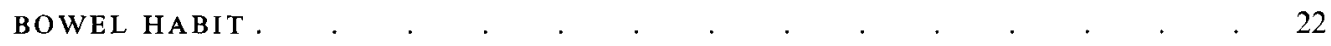

BILE ACID METABOLISM . . . . . . . . . . . . . . . . . . 22

\begin{tabular}{l} 
CALCULATING THE ENERGY VALUE OF RESISTANT STARCH IN \\
MAN \\
\hline
\end{tabular}

(Working group IV, Chairman G. Livesey)

CONCLUDING REMARKS AND FURTHER RESEARCH NEEDS . . 23

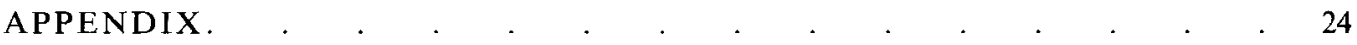

REFERENCES . . . . . . . . . . . . . . . . . . . . .

\section{INTRODUCTION AND DEFINITION OF RESISTANT STARCH}

\section{EVOLUTION OF THE RESISTANT STARCH CONCEPT}

Until recently, starch was generally regarded as completely digested and absorbed in the small intestine, at least after cooking. Some studies challenged this concept by demonstrating starch in human faeces (Van der Westhuizen et al. 1972; Wolf et al. 1977) or breath hydrogen excretion related to the consumption of starch in foods (Anderson et al. 1981). The observation by Englyst et al. (1982), in the process of developing a technique for measurement of dietary fibre, that enzyme resistant starch appeared together with the non-starch polysaccharides (NSP) of some processed foods provided the starting point for the present interest in resistant starch (RS). It was then directly demonstrated by experiments with ileostomates, that starch was passing right through the small intestine after ingestion of foods such as cereals, bananas and potatoes (Englyst \& Cummings, 1985, 1986, 1987). Based on these and similar studies, Englyst and colleagues (Englyst \& Cummings, 1990; Englyst \& Kingman, 1990) concluded that the starch referred to in 1982 as RS was only part of the starch that escaped digestion and absorption in the human small intestine, and they extended the definition of RS to include all the starch that escapes digestion in the small intestine.

Research on dietary fibre has demonstrated the importance of fermentation of indigestible carbohydrates in the human colon. A main reason for the present great interest in RS is that it provides a substrate for the microflora of the large intestine, although possible effects in the upper intestinal tract have also been explored. In vitro studies using human faecal inocula had shown that starch from various sources was fermented (Englyst \& Macfarlane, 1986; Wyatt \& Horn, 1988). From a food technology point of view it is challenging that the RS content of foods can be varied within wide limits by choice of raw material and processing conditions.

\section{DEFINITION OF RESISTANT STARCH}

Resistant starch is the sum of starch and the products of starch degradation not absorbed in the small intestine of healthy individuals (Asp, 1992b). 
A1

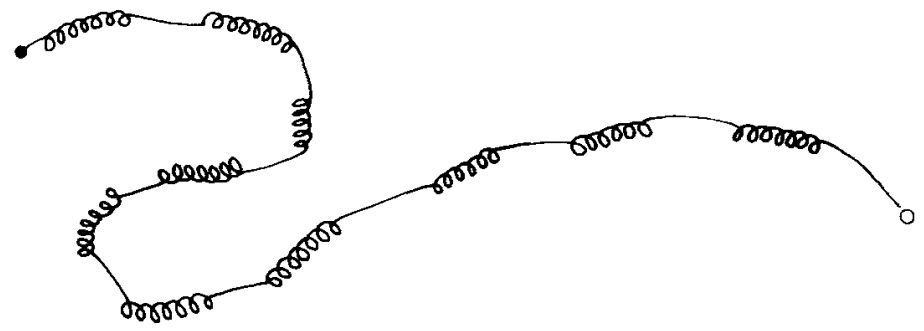

A2

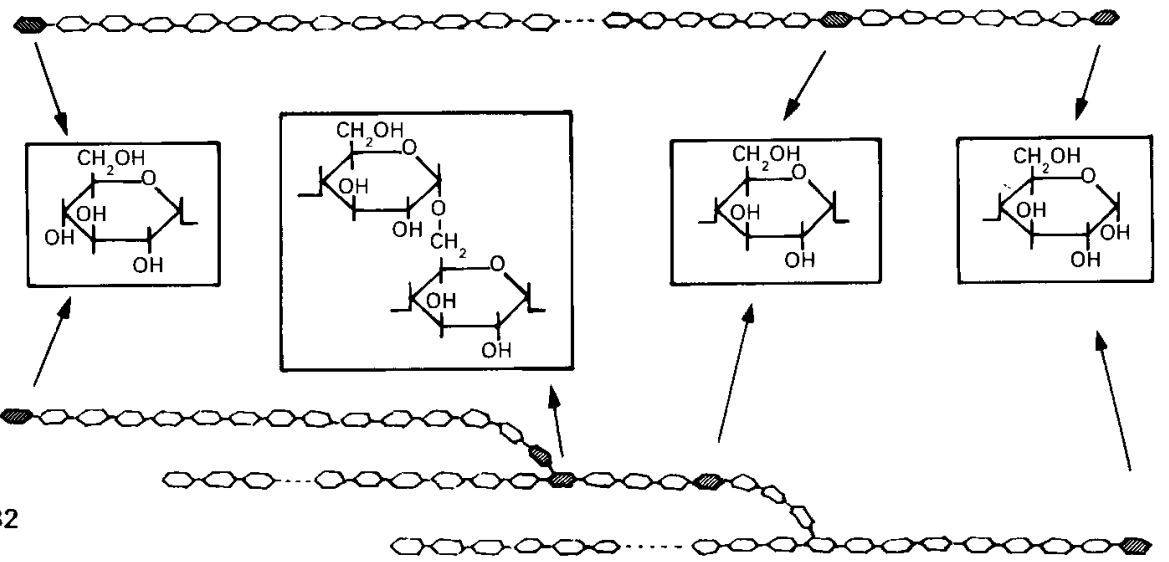

C1

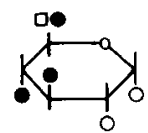

C3

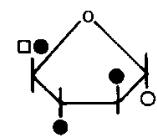

C5

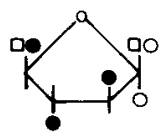

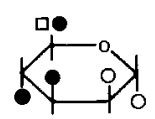

$\mathrm{C} 2$
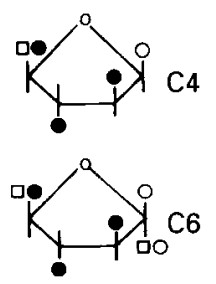

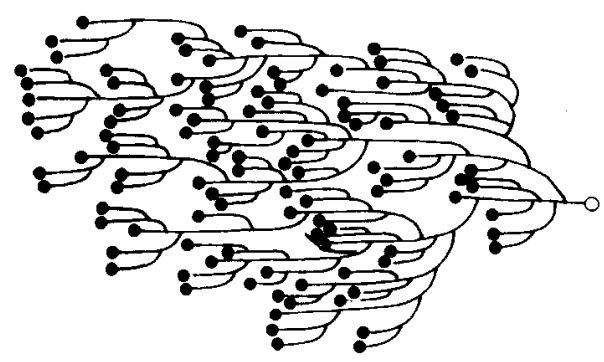

B1 


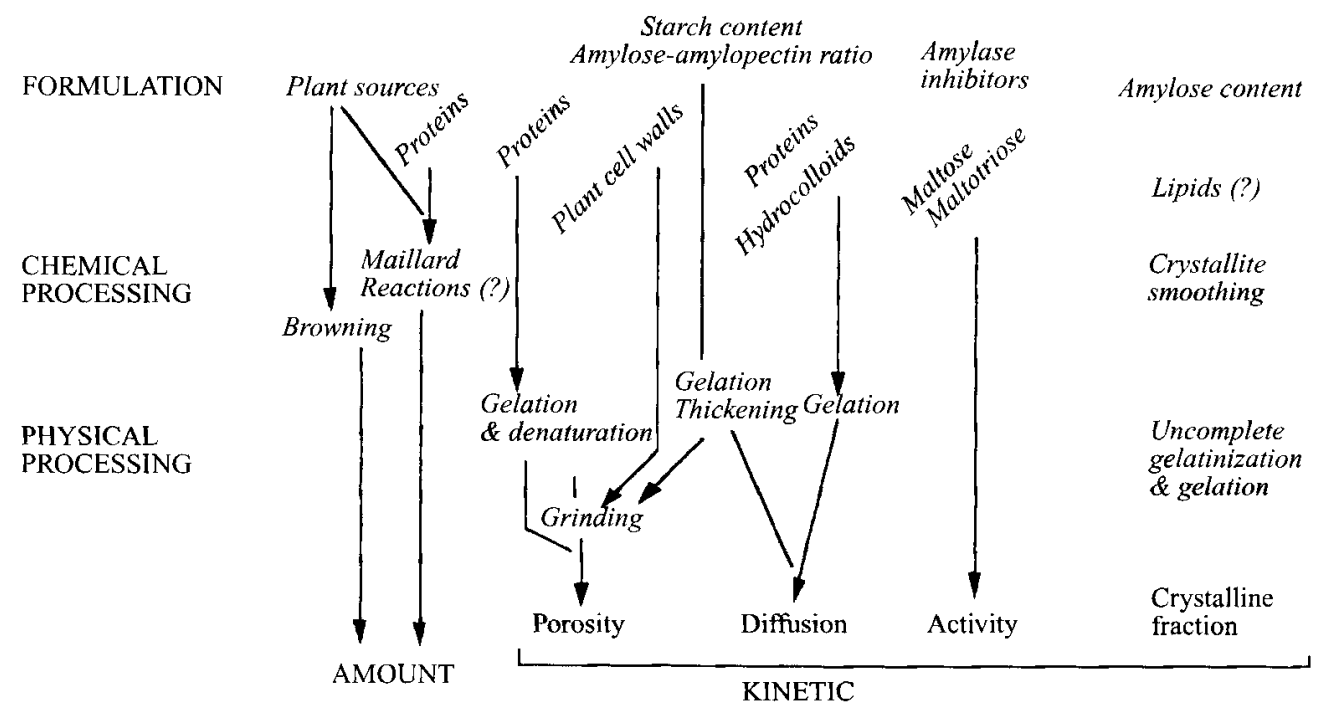

Fig. 2. Factors involved in the kinetics of starch hydrolysis by $\alpha$-amylases (from Colonna et al. 1992). The effect of formulation and processing on the amount of resistant starch is illustrated as well as factors influencing hydrolysis kinetics, such as porosity, enzyme diffusion and activity, and crystallinity.

\section{PHYSICAL AND CHEMICAL CHARACTERISTICS, AND ANALYSIS OF RESISTANT STARCH}

\section{STARCH - THE MOST ABUNDANT COMPONENT OF THE DIET}

Starch is quantitatively the most important component of diets and a major source of dietary carbohydrate. It is composed of two principal macromolecules, amylose and amylopectin, the structures of which are illustrated in Fig. 1. For a review, see e.g. Gallant et al. (1992).

Amylose is a long, essentially linear polymer consisting of 1,4- $\alpha-\mathrm{D}-\mathrm{anhydroglucose}$ units with a few $\alpha-1,6$-linked units. The 1,4-linked anhydroglucose units produce a gradual, natural twist of the amylose molecule in a helical conformation with six glucose residues per turn. In this structure, all the hydrophilic hydroxyl groups of the chain are on the external side of the helix, creating a hydrophobic cavity inside the helix, into which many small molecules can be bound, for instance the carbon chain of fatty acids (amylose-lipid complexes) and iodine (blue colour).

Amylopectin is one of nature's largest molecules (molecular weight $10^{7}-10^{9}$ ) and has a branched structure with about $5 \%$ of the anhydroglucose units having $1,6-\alpha$-linkages. The structure is a clustering of many short 1,4- $\alpha$-linked chains with an average length of 20 (range 12-70) glucose residues. The three-dimensional structure of amylopectin is not yet known in detail, but the main features are illustrated in Fig. 1.

Plants store starch in condensed granules of varying size and shape characteristic for each plant. Tuber starches, e.g. potato starch, are generally large ellipsoid or spherical granules, whereas cereal starches are small and polyhedric granules. Some cereals, e.g. wheat, also contain larger, lentil-shaped granules. Legume starches are generally kidneyshaped or ovoid.

The crystallinity of native starch granules varies from 15 to $45 \%$, the remainder having an amorphous structure. Three crystalline forms, A, B and C, of starch granules have been identified from different diffractometric spectra. Cereal starches generally display the 
A-form, whereas potatoes and some tropical tubers give the B-form. Most legume starches have the $\mathrm{C}$-pattern, considered by some either as a distinct crystallographic pattern or a mixture of the A- and B-patterns.

The A pattern has water molecules located between the double helix-formed starch molecules (Imberty et al. 1988). In the B structure the double helices are packed densely in a hexagonal pattern with water molecules inside this structure only (Imberty \& Pérez, 1988).

Native starch granules are slowly hydrolysed when exposed to amylases, B-type granules more slowly and less completely than A-type. The amorphous parts are most easily degraded and the granules become eroded. Most granules are first hydrolysed superficially, whereas extremely resistant granules, such as amylomaize, may be endocorroded, i.e. hydrolysed from the interior after penetration of enzyme through surface pores.

On heating above the gelatinization temperature, which varies with different starches, and with water in excess, the granules undergo swelling and partial solubilization, especially of amylose. This is due to breaking of hydrogen bonds between the starch molecules and intramolecular side chains. With lower water content as is often the case in foods, the crystallites melt at higher temperatures $\left(>100^{\circ} \mathrm{C}\right)$.

Gelatinized starches are unstable and tend to reassociate upon lowering the temperature and at the water content of many foods. Gelation is the first step in this process. On ageing, the gels develop a B-type crystallinity. This is referred to as retrogradation. Repeated thermal treatments increase the retrogradation by increasing interchain amylose associations (for a review, see Colonna et al. 1992).

\section{FACTORS AFFECTING ENZYMIC HYDROLYSIS OF STARCH}

Colonna et al. (1992) reviewed factors affecting the enzymic hydrolysis of starch. The salivary and pancreatic amylases hydrolyse the $\alpha-1,4$ bonds of amylose and amylopectin. These enzymes are able to bypass, but not to hydrolyse, the $\alpha-1,6$ bonds of the branching points. The hydrolysis products are mainly maltose, glucose and dextrins containing the branching points. The intrinsic hydrolases of the small intestinal brush border membrane complete the hydrolysis to free glucose.

Amorphous or dispersed starch found in freshly cooked starchy foods is highly susceptible to salivary and pancreatic amylases. Some substances inhibit $\alpha$-amylase (EC $3.2 .1 .1)$ activity in vitro: (1) proteins or glycoproteins present in legumes, but also in cereals, which are generally inactivated during cooking; (2) antinutrients such as tannins and polyphenols, which are more thermoresistant; and (3) hydrolysis products, especially maltose and maltotriose, that are further hydrolysed and absorbed, and thus of less importance in vivo.

Release of oligosaccharides from solid starchy substrates, such as starch granules or retrograded amylose, has more complicated kinetics. Colonna et al. (1992) used a mechanistic approach of hydrolysis by $\alpha$-amylase in solution, and considered four successive phases: (1) the diffusion of the enzyme molecule towards its substrate; (2) the porosity of starchy substrates; (3) the adsorption of enzymes on the substrate; and (4) the catalytic event. These steps are influenced by a large number of properties in the raw material, as well as processing and storage conditions of foods, as shown in Fig. 2.

\section{MAIN FORMS OF RESISTANT STARCH}

There are a number of different reasons why starch in foods may be incompletely digested and absorbed during passage through the small intestine. Englyst \& Cummings (1987) differentiated three main forms of RS : (1) starch that is physically inaccessible to digestive 
enzymes owing to enclosure in food structures such as intact cells or partly milled or whole grains or seeds; (2) resistant B-type starch granules occurring in (uncooked) potatoes and green banana; and (3) retrograded amylose occurring in processed foods. These forms have been named RS 1, 2 and 3 respectively (Englyst \& Cummings, 1990; Englyst \& Kingman, 1990).

Although the three main forms of RS probably represent the main forms of indigestible starch in most foods, a number of other reasons for resistance should be kept in mind: amylose-lipid complexation, retrogradation of amylopectin, and the creation of new enzyme resistant glycosidic bonds by dry heating at high temperature (Asp \& Björck, 1992).

\section{CHARACTERIZATION OF RESISTANT STARCH OBTAINED IN VIVO}

Before 1993 there were only a few studies characterizing RS (as defined above) obtained in vivo from humans (Champ, 1995). Starch recoveries in ileostomy effluents after consumption of various foods and diets were reviewed by Andersson (1992) and found to range from $<1 \%$ to $75 \%$ of the ingested starch, the latter figure relating to green bananas (Englyst \& Cummings, 1986). Englyst \& Cummings (1985, 1986, 1987) and Schweizer et al. (1990) identified both potentially digestible 'dietary starch' and 'resistant starch', defined as a fraction requiring solubilization with $\mathrm{KOH}$ or dimethylsulphoxide before hydrolysis, in ileostomy effluents. Low molecular weight dextrins and glucose were also identified.

The characterization of in vivo RS after ingestion of foods or reference materials containing various types of RS has been an important part of the work carried out within EURESTA and the physical characteristics of these reference materials are summarized in Table 1. Faisant et al. $(1993 a c, 1994,1995 a-c)$ and Noah et al. (1995) showed three different fractions (Champ, 1995): (1) residues of starch granules and/or long chains of soluble starch molecules (degree of polymerization (DP) $>100$ ); (2) a crystalline fraction with linear chains (DP about 26-38, expressed as weight average degree of polymerization); and (3) oligosaccharides with DP 5 or less together with free glucose. These fractions were found at the end of the ileum after ingestion of various sources of RS. The intermediate molecular weight fraction predominated after ingestion of retrograded or lipid complexed high amylose corn starch, constituting about $80 \%$ of the total RS. It was also the major fraction of RS found in dry beans cooked and stored at $-20^{\circ} \mathrm{C}$ overnight before being eaten (Noah et al. 1995). The high molecular weight fraction was most prominent after consumption of green banana flour (87\%; Faisant, 1994), and $34 \%$ and $25 \%$ of the in vivo RS after bean flakes and potato flakes respectively (Faisant et al. 1993 c). The small amount of RS following consumption of potato flakes contained mainly low molecular weight components.

Ekwall et al. (1995b) studied RS obtained in vivo from ileostomates after ingestion of diets containing autoclaved high amylose corn starch (in vivo RS content $44 \%$ of dry matter) or drum dried ordinary corn starch (in vivo RS $4 \%$ ). They also identified three RS fractions. The main fraction in the effluent in both cases had an average DP $\sim 80, \sim 5 \%$ of the RS was recovered in the low molecular weight fraction, and there were trace amounts of a high molecular weight fraction. A considerable part of the RS was available to enzymic degradation without solubilization, i.e. 'dietary starch' analytically.

Botham et al. (1995) reported a wide range of molecular weights in in vivo RS after a meal containing retrograded starch gel, with a main fraction containing amylose fragments with DP $70-80$.

In conclusion, $\mathrm{RS}$ is composed of three main fractions, i.e. glucose and oligosaccharides, a crystalline fraction with intermediate molecular size, and a high molecular weight fraction 


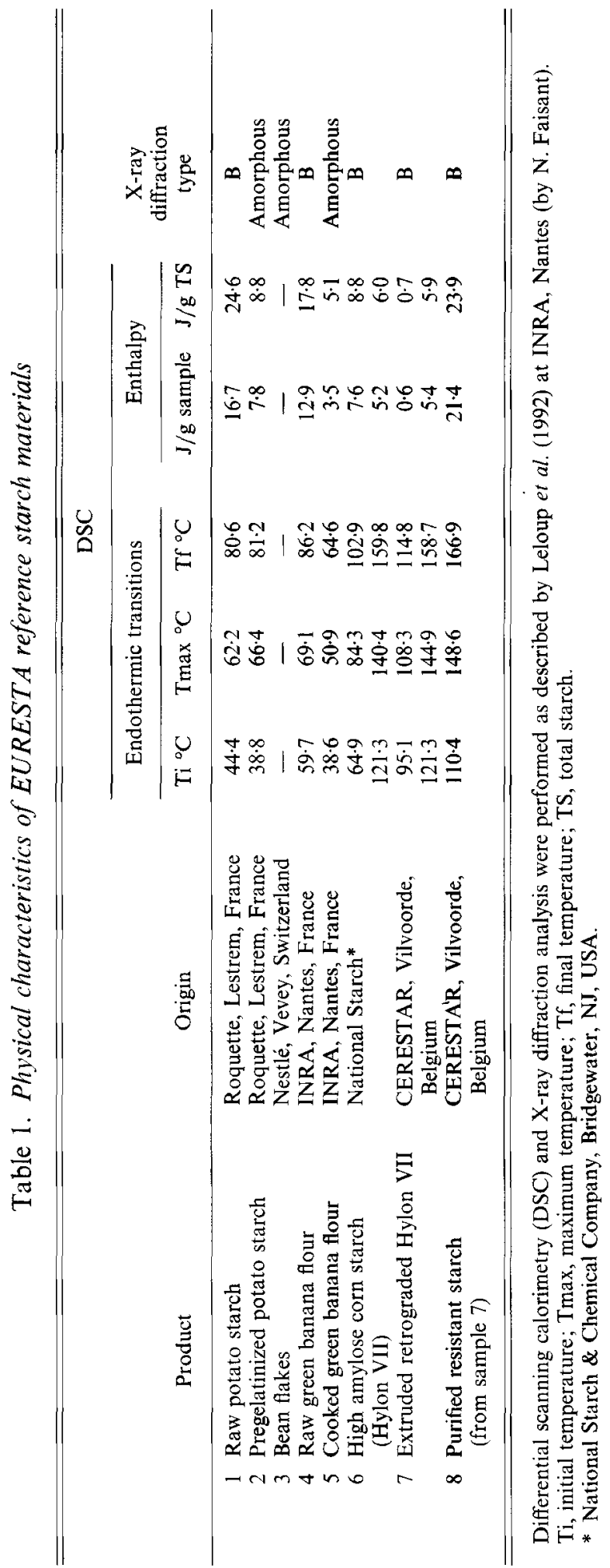


containing residues of resistant granules as well as physically enclosed starch. The relative size of these fractions varies depending upon the source of the RS. Somewhat varying estimates have been obtained regarding the molecular size of the intermediate fraction. It is not clear whether this represents a true variation in DP of this fraction from various sources, or arises from methods used.

The presence of a low molecular weight RS fraction composed of oligosaccharides that are available for amylase digestion, and even free glucose, deserves special consideration. The digestion of starch in foods containing RS obviously continues throughout the small intestine. The low molecular weight fraction would then represent starch partly hydrolysed in the distal small intestine without being finally hydrolysed and absorbed. The failure of absorption in the distal small intestine may be simply due to lack of time, but the comparatively low activities of brush border hydrolases and limited capacity of glucose transport may also contribute to the malabsorption. Disaccharidase activities are maximal in the proximal and central parts of the small intestine; maltase (EC 3.2.1.20) and isomaltase ( $E C 3.2 .1 .10)$ activities decline to half maximal or less in the distal ileum (Asp et al. 1975). Finally, some continued hydrolysis after collection of the ileostomy evacuates cannot be excluded, but it should be noted that low molecular weight material was identified also in ileal content collected by intubation (Faisant, 1993c).

\section{ANALYSIS METHODS FOR RESISTANT STARCH IN VITRO}

The first method for analysis of RS was devised by Englyst et al. (1982) when discovering the enzyme resistant starch fraction in analysing foods for NSP: the difference between NSP glucose with and without solubilization with $\mathrm{KOH}$ or dimethylsulphoxide before the amylase/pullulanase (EC 3.2.1.41) hydrolysis of starch.

Johansson et al. (1984) and Björck et al. (1986) proposed a different method based on the measurement of starch remaining in a residue prepared for gravimetric measurement of dietary fibre (Asp et al. 1983). Heat resistant $\alpha$-amylase (Termamyl) and pancreatin were used for starch hydrolysis. Residual starch was measured before solubilization, and total starch after solubilization with $\mathrm{KOH}$. RS was calculated as the difference between total and residual starch. This type of method, as well as the original one of Englyst et al. (1982), includes milling and gelatinization steps. Of the three main forms of RS, therefore, these methods can be expected to measure only RS 3. The method based on determining starch in a dietary fibre residue has been simplified for the purpose of measuring RS by SauraCalixto et al. (1993).

Berry (1986) published a method based on extensive $\alpha$-amylolysis at $37^{\circ} \mathrm{C}$ without gelatinization. Thus, resistance due to raw starch granules (RS 2) would be recovered, but still not RS 1 . This method was slightly modified by collaborators of the EURESTA project (Method A) and tested together with the method of Björck et al. (1986) (Method B) in a first collaborative study within the project (Champ, 1992). Several methods were also used to determine total starch. Four different RS-containing materials were analysed: bean flakes, pregelatinized high amylose corn starch, Kellogg's corn flakes and raw potato starch. Method A gave higher values of RS in all materials. As expected, Method B did not detect any RS in the raw potato starch due to the gelatinization step included in that method. From the experiences obtained in this first interlaboratory study, further minor but important modifications of the Berry method were suggested by Goñi et al. (1996) and by the Unilever Research Laboratory (reported by Champ, 1992). These modifications, and an increased amyloglucosidase ( $E C$ 3.2.1.3) concentration to ensure a complete hydrolysis when analysing samples with a very high RS content, were included in the modification published by Faisant et al. $(1995 d)$. 
Table 2. EURESTA reference materials: content of dry matter, total starch and various starch fractions (expressed as $\mathrm{g} / 100 \mathrm{~g}$ as received) with the method of Englyst et al. (1992), provided by Dr H. Englyst, and with the method of Berry (1986) as modified by Faisant et al. (1995d)

\begin{tabular}{|c|c|c|c|c|c|c|}
\hline Product & $\begin{array}{c}\text { Dry } \\
\text { matter }\end{array}$ & $\begin{array}{l}\text { Total } \\
\text { starch }\end{array}$ & $\begin{array}{l}\text { Readily } \\
\text { dig. } \\
\text { starch }\end{array}$ & $\begin{array}{l}\text { Slowly } \\
\text { dig. } \\
\text { starch }\end{array}$ & $\begin{array}{l}\text { Resistant } \\
\text { starch }^{1}\end{array}$ & $\begin{array}{c}\text { Resistant } \\
\text { starch }^{2}\end{array}$ \\
\hline 1 Bean flakes & $92 \cdot 0$ & $43 \cdot 3$ & $31 \cdot 4$ & $7 \cdot 3$ & $4 \cdot 6$ & $4 \cdot 6$ \\
\hline 2 Raw potato starch & $83 \cdot 4$ & $81 \cdot 3$ & 6.0 & $21 \cdot 2$ & $54 \cdot 1$ & $63 \cdot 3$ \\
\hline 3 Raw green banana & $99 \cdot 2$ & $72 \cdot 8$ & $3 \cdot 0$ & $15 \cdot 7$ & $54 \cdot 2$ & $47 \cdot 3^{*}$ \\
\hline $\begin{array}{l}470 \% \text { amylose corn } \\
\text { starch }\end{array}$ & $89 \cdot 3$ & 86.0 & $8 \cdot 4$ & $16-2$ & $61 \cdot 4$ & $48 \cdot 8$ \\
\hline $\begin{array}{l}5 \text { Extruded retrograded } \\
70 \% \text { amylose corn } \\
\text { starch }\end{array}$ & $91 \cdot 2$ & $89 \cdot 9$ & $47 \cdot 2$ & $15 \cdot 3$ & $27 \cdot 4$ & $29 \cdot 8$ \\
\hline $\begin{array}{l}6 \text { Resistant starch } \\
\text { purified }\end{array}$ & $96 \cdot 2$ & $92 \cdot 5$ & $12 \cdot 0$ & $10 \cdot 8$ & $69 \cdot 8$ & - \\
\hline
\end{tabular}

1 Method of Englyst et al. (1992).

${ }^{2}$ Method of Berry (1986) as modified by Faisant et al. $(1995 d ; * 1995 a)$.

Englyst et al. (1992) devised a scheme for the classification and measurement of nutritionally important starch fractions including the three main forms of RS. The method is based upon analysis of starch fractions in foods as eaten, which is the basis for recovering even the physically enclosed RS 1 . Whereas chewing would be the ideal way of disintegrating foods to mimic normal eating, mincing and standardized milling with glass balls in the presence of guar gum to increase the viscosity during the amylase digestion was chosen as a more convenient way in practice. The different starch fractions are then separated as readily digestible starch, slowly digestible starch and RS, with the possibility to determine the different forms of RS separately. The method was validated by them for a limited number of substrates in ileostomates. An in vitro RS assay that used chewing as the initial disintegration step was developed (Muir \& O'Dea, 1992) and validated against in vivo studies in human ileostomates (Muir \& O'Dea, 1993; Muir et al. 1995).

The Englyst method was first evaluated in a separate collaborative trial (Englyst et al. 1992), and in a second study the modified Berry method according to Champ (1992) and the Englyst method were further tested and compared (Dysseler \& Hoffem, 1995a, $b$ ). Working group I (Champ, 1995; Champ \& Faisant, 1995) drew some general conclusions from these method studies within the EURESTA project (Table 2):

- In general the two methods give very similar values for samples with a high level of RS.

- The modified Berry method is quicker and easier to reproduce than the Englyst method.

- Analysis of physically inaccessible starch is not solved by the modified Berry method.

- The Berry method as modified by Champ (1992) has only been validated against Englyst's method; few comparisons with in vivo data have been made.

- Englyst's method may reflect better the in vivo physiology than the other methods.

- There is a need for more in vivo studies (ileostomy and intubation) on real foods (as eaten). 
- Further analytical studies have to be performed before any method can be recommended for labelling of RS.

\section{RESISTANT STARCH INTAKE IN EUROPE}

The RS intake in 10 different European countries was evaluated from national consumption statistics regarding starchy foods (Dysseler \& Hoffem, 1995c). The calculations were based on literature data with the Englyst method (Englyst et al. 1992) or separate analyses of foods with the Englyst method or the modified Berry method (Champ, 1992). The mean RS intake according to these calculations would be $4.1 \mathrm{~g} / \mathrm{d}$, with variation from $3 \cdot 2$ to 5.7 between different European countries. Owing to differences in kind and completeness of data as well as in analytical methods, the data should be regarded as indicative only, and this survey did not allow any detailed comparison between countries. There is an obvious need for these intake data to be completed, and the main starch-containing foods analysed as eaten.

The present RS intake in Europe seems low but there is a considerable potential to increase the intake by new products with increased RS content, if RS proves to be beneficial to the consumer.

\section{TECHNOLOGY OF RESISTANT STARCH PRODUCTION}

Both the choice of raw materials and the methods and conditions for processing can affect the RS content of food ingredients and food products within wide limits. Disintegration of gross and cellular structures releases physically enclosed starch and thereby reduces the RS 1 content. Gelatinization, which is usually more or less complete in most starchy foods as eaten, with the exception of unripe fruits, would diminish RS 2 from RS granules. RS 3 is formed by retrogradation of amylose during processing, cooling and storage under moist conditions. The importance of amylose-lipid complexes, amylopectin retrogradation, chemical modification and heat treatments in dry conditions is difficult to assess at present (for review on the formation, structure and properties of RS 3 see e.g. Eerlingen \& Delcour, 1995).

The great impact of food processing on RS warranted a separate group working on technological aspects, and aiming to provide suitable reference materials with different forms of RS for analytical and physiological studies (Würsch \& Delcour, 1995).

\section{FORMATION OF RESISTANT STARCH UNDER VARIOUS CONDITIONS}

The RS content of common cereal foods like bread, breakfast cereals, pasta and rice is generally below $3 \%$, potato $4-5 \%$, potato flakes $3 \%$ (all figures on a dry matter basis, determined by the modified Berry method (Method A; Würsch \& Delcour, 1995)). French fries contained $1.4 \%$ on a fat free basis, whereas Bravo et al. (1995) reported up to $32 \%$ RS in fried, freeze-dried and defatted potato chips.

Leguminous seeds generally have a comparatively high content of RS after processing for two reasons: the high resistance of cells towards disintegration in cooking, and the high content of amylose, $>30 \%$ (Tappy et al. 1986; Tovar et al. 1990, 1992). Cooking and freeze drying of milled and whole lentils (Lens culinarus medicus) made $9 \%$ of the starch resistant, and in peas $13 \%$. Extrusion cooking of peas, on the other hand, gave only 
1-1.5\% RS (Würsch \& Delcour, 1995). Englyst et al. (1992) reported the content of RS in various starch fractions of 34 different foods as determined by their method. Levels of RS in legumes ranged from 5 to $18 \%$ of the dry matter, corresponding to $12-40 \%$ of the starch.

$\mathrm{RS}$ in common foods can be increased by prolongation of the moist stage after cooking, by repeated cycles of heating and chilling, or by freezing. Storage of foods such as bread (30-40\%) water), on the other hand, does not seem to increase the RS content (Rabe \& Sievert, 1992). Using a high pressure autoclave process, Escarpa et al. (1996) reported better control of gelatinization and increased RS yield in potato amylose and amylopectin mixtures.

Eerlingen (1994) and Eerlingen et al. (1993a, b, $1994 a-d$ ) made a series of studies on the formation of RS 3 . Ordering of amylose chains resulting in RS formation occurs during rapid cooling $\left(10^{\circ} \mathrm{C} / \mathrm{min}\right)$ to below $60^{\circ} \mathrm{C}$ of an amylose solution heated up to $180^{\circ} \mathrm{C}$ (Sievert \& Würsch, 1993a). Enzyme resistant starch formed from amylose fractions with different chain lengths differed in RS yield but not in RS quality (Eerlingen et al. 1993b). In all cases, the isolated RS samples were of the B-crystalline type with similar chain lengths (number average degree of polymerization, $\mathrm{DP}_{n}$, between 19 and 26, corresponding to about two times higher weight average degree of polymerization, $\mathrm{DP}_{\mathrm{w}}$ ). Storage of gelatinized starch for several days at temperatures between 0 and $68{ }^{\circ} \mathrm{C}$ also produced 4-6\% RS with B-type crystallinity, whereas storage at $100{ }^{\circ} \mathrm{C}$ yielded about $10 \% \mathrm{RS}$ with an A-type crystalline structure (Eerlingen et al. 1993a).

Amylopectin, present in most starches, interferes with the ordering of amylose, thus inhibiting RS 3 formation (Sievert \& Würsch, 1993a; Eerlingen et al. 1994b). The outer short chains of amylopectin can reorganize during storage of gelatinized high amylopectin maize starch, but the melting temperature of these crystallites is rather low, $\sim 65^{\circ} \mathrm{C}$ compared with $150^{\circ} \mathrm{C}$ for crystallites obtained from amylose and constituting RS 3. Leloup et al. (1992) reported melting temperatures of around $125^{\circ} \mathrm{C}$ and $46^{\circ} \mathrm{C}$ for amylose and amylopectin respectively.

The importance of amylopectin retrogradation for in vivo RS formation is not fully explored. When amylopectin is extensively retrograded, as in stale bread, the rate of hydrolysis with pancreatic $\alpha$-amylase at $37^{\circ} \mathrm{C}$ in vitro is reduced, but the final extent of hydrolysis is not affected (Eerlingen et al. $1994 b$; Würsch \& Delcour, 1995). As pointed out by Englyst \& Cummings (1987), amylopectin retrogradation may account for the high in vivo RS content found in cooked and cooled potatoes. The fact that the amylopectin from potato has longer outer chains than that from cereals could make retrograded potato amylopectin more resistant.

Added and endogenous lipids are other factors influencing RS formation through complexation with amylose. Such a complex would hinder double helix associations, thus inhibiting RS formation (Sievert \& Würsch, 1993b; Eerlingen et al. 1994a). On the other hand, amylose-lipid complexes are more slowly digested and absorbed than free amylose (Holm et al. 1983), and may contribute to RS (Faisant et al. 1993c).

Four products with high RS content were available for production of RS foods: raw potato starch, unripe banana, amylomaize starch, and retrograded amylomaize starch. In the case of potato starch and banana, heating conditions have to be carefully controlled to avoid gelatinization (Würsch \& Delcour, 1995). Eerlingen et al. (1994d) reported the production of a conventional straight dough bread with high RS content (up to $11 \%$ of the starch) and maintained texture and taste. The flour was partly replaced by raw or retrograded amylomaize starch $(70 \%$ amylose $)$ and gluten. Liljeberg and coworkers (Liljeberg \& Björck, 1994; Liljeberg et al. 1995) reported $8 \%$ RS in a commercial pumpernickel bread. The long time-low temperature baking conditions used obviously favour RS formation. Porridge from high amylose barley and corn griddle cake (arepa) 
prepared with high amylose corn varieties were other products with high amounts of RS. Such products would enable a considerable increase in the RS intake.

\section{PRODUCTION OF REFERENCE MATERIALS}

A number of reference materials were selected to include the three main forms of RS. It has been demonstrated that leguminous seeds can be processed with preservation of cellular structures (Tappy et al. 1986). This process was used to produce flakes from white beans (Phaseolus vulgaris) as a reference material by soaking, cooking and roller drying. Such material would be expected to contain physically enclosed starch (RS 1), but also retrograded amylose (RS 3), owing to the high amylose content (28-35\%, Würsch \& Delcour, 1995).

Three different materials were used as sources of RS granules (RS 2): raw potato starch, a flour from raw, freeze-dried green bananas, and a raw high amylose corn starch (Hylon VII). Pregelatinized potato starch and flour from cooked green bananas, containing marginal levels of RS, were also provided to serve as controls.

To provide reference material with high content of RS 3, the high amylose corn starch was extrusion cooked under conditions favouring retrogradation of amylose. Subsequently, the RS in this sample was enriched by treatment with pancreatic $\alpha$-amylase to remove available starch.

The physical characteristics of these samples, measured by differential scanning calorimetry and X-ray diffraction, are shown in Table 1, and the contents of resistant and digestible starch in Table 2.

Food technologists and ingredient suppliers were quick to realize that processing techniques increasing the amount of RS in foods would have potential nutritional and commercial value. Autoclaved cereal starches were the first RS-containing materials to be characterized, and this led to the expression 'man-made fibre' to designate retrograded amylose. Two starches with a high content of RS are already commercially available (Novelose $^{\mathrm{TM}}$, National Starch \& Chemical Company, and Crystalean ${ }^{\mathrm{R}}$, Opta Food Ingredients, Inc.); they are probably both obtained from high amylose corn starch treated to promote retrogradation. These products can easily be incorporated into a number of foods such as breads or cookies. Optimal conditions for retrogradation depend on the nature of the starch, but appear to be in most cases $\sim 4{ }^{\circ} \mathrm{C}$ with a hydration level $>70 \%$ (Champ \& Faisant, 1996).

\section{PHYSIOLOGICAL EFFECTS IN THE UPPER GASTROINTESTINAL TRACT}

By the definition mentioned above, RS is not absorbed in the small intestine of healthy individuals. Therefore, it is not digested to free glucose and does not provide glucose to the body, although partial enzymic degradation would in principle be possible. The presence of RS in the gut digesta could also influence gastric emptying and digestion of other nutrients, and satiety. The possibility of interference with the absorption of other compounds was also considered.

Glucose from rapidly digested starch is absorbed in the first part of the small intestine. That from more slowly digested starch can be expected to be absorbed more distally. When RS is present in the diet, starch digestion should theoretically take place throughout the whole length of the small intestine, so that glucose absorption may occur even in the terminal ileum.

In addition to the intrinsic properties of foods affecting starch digestibility, a number of physiological variables could be expected to affect the final starch digestibility, and thereby 
the in vivo RS content. These have been called 'extrinsic factors' (Englyst et al. 1992) and include: the extent of chewing, the mouth to terminal ileum transit time, the amylase concentration in the gut, the amount of starch present, and any food components that might retard starch hydrolysis.

How much starch actually leaves the small intestine is of key importance in assessing the physiological effects of RS, and as a reference in the development of in vitro methods. Three different methods were used in human subjects - breath hydrogen and methane excretion tests, ileostomates, and intestinal intubation. Furthermore, a number of animal models were used and evaluated.

\section{HYDROGEN AND METHANE BREATH TESTS}

Hydrogen is formed in the body exclusively by bacterial fermentation in the gut. A fraction is absorbed and cleared in a single passage through the lungs. The major substrate is carbohydrate reaching the colon, and the breath hydrogen test has, therefore, been used extensively for the determination of malabsorbed carbohydrate, including RS (Anderson $e t$ al. 1981), and also to assess the mouth to caecum transit time.

Hydrogen that is not absorbed can be eliminated by routes such as methane production, sulphate reduction and acetogenesis (Gibson et al. 1990). Therefore, no simple stoichiometric relation exists between the amount of fermentable substrate (and hydrogen production) and breath hydrogen excretion. As reported by Christl et al. (1992), an increasing rate of hydrogen production results in reduced fractional disposal of hydrogen through the lungs.

Rumessen (1992) reviewed the hydrogen and methane breath tests for evaluation of resistant carbohydrates. The need for unabsorbable standards to compensate for the large interindividual variation was stressed. He concluded that measurement of breath methane might give supplementary information but this needed further evaluation.

Olesen et al. (1994) demonstrated that raw potato starch increased the breath hydrogen excretion with a dose-response relationship, although the response occurred later and had a longer duration than after wheat or oat bran. Raw potato starch even produced an elevated basal hydrogen excretion if measured after $12 \mathrm{~h}$ fasting. RS preparations with mainly retrograded amylose from the high amylose maize starch also tended to increase the breath hydrogen, but not significantly. There was no measurable increase in methane excretion after any of the resistant starch preparations. A far more pronounced breath hydrogen increase was found after ingestion of $200 \mathrm{~g}$ white wheat bread, indicating a considerable malabsorption of starch from ordinary bread, at least when eaten in such a high amount (Olesen \& Gudmand-Høyer, 1995). A considerable breath hydrogen increase after white bread has previously been demonstrated (Anderson et al. 1981; Levitt et al. 1987).

In conclusion, $\mathrm{RS}$ results in measurable breath hydrogen increments due to fermentation. However, the response is quite prolonged, making very long follow-up periods necessary, and the results are semiquantitative only.

\section{THE ILEOSTOMY MODEL}

There are two different methods available for sampling digesta leaving the small intestine: experiments with ileostomates and intubation of healthy volunteers.

Use of the ileostomy model for the study of carbohydrate digestion and absorption and for effects of carbohydrates on sterol excretion was reviewed by Andersson (1992). The main advantage is direct and quantitative collection of ileal effluents over a defined period of time. A key issue is to avoid bacterial degradation during collection and handling of the 
effluent. The almost quantitative recovery of dietary fibre components, and minimal degradation of bile acids and neutral sterols, confirm that this can be achieved in practice (for review, see Andersson, 1992). Furthermore, Cummings \& Englyst (1991) found less than $5 \mathrm{mmol} / 1$ of short chain fatty acids (SCFA) in ileostomy effluent - a low although not zero figure which is compatible with the finding of a 100-fold increased bacterial count in the terminal ileum of ileostomy subjects, compared with the normal ileum (Finegold et al. 1970). The general opinion among EURESTA participants was therefore that bacterial fermentation in the ileum of ileostomy subjects is minimal and does not compromise results in practice (Cummings, 1992). There is an abundance of active pancreatic enzymes in the ileal effluents (for review, see Andersson, 1992), which means that some continued degradation of for instance starch in the collection bags before cooling is possible.

The relatively short oro-caecal time in ileostomates, compared with the total transit time where the colon is intact, means that balance experiments with accurate demarcation of the balance period can be performed within $24 \mathrm{~h}$. A fasting period overnight is sufficient to ensure complete excretion of all food residues from the previous day (Andersson, 1992). The scheme, as developed in Cambridge, requires all the food under investigation to be given at breakfast. In this case the corresponding collection period can then be completed the same evening (Englyst \& Cummings, 1985, 1986, 1987).

The key question remains as to whether the ileal function in ileostomates can be regarded as normal. There is a significant adaptation of the digestive and absorptive capacity in the distal ileum after establishment of the ileostomy. Adaptation to a varying extent also occurs in electrolyte and fluid absorption capacity. For this reason, it is recommended that investigations regarding, for example, starch absorption are based on groups of subjects (Andersson, 1992, 1995). No evidence of adaptation in starch absorption has however been obtained (Cummings, 1992; Andersson, 1992). Andersson (1995) compared two studies in which ileostomates had been tested in the early postoperative state (Andersson et al. 1984a), and more than six months postoperatively (Andersson $e t a l .1984 b$ ). The excretion of energy and carbohydrate (by difference) was similar.

For this type of study, the importance of selecting ileostomy subjects operated on for ulcerative colitis, with minimal ileal resection, has been stressed (Andersson, 1992; Cummings, 1992). Such subjects have bile acid losses of less than $1 \mathrm{~g} / \mathrm{d}$ (Bosaeus \& Andersson, 1987) and serum cholesterol concentrations in the normal range (Ellegård \& Bosaeus, 1991).

Andersson (1992) reviewed the data on starch excretion in ileostomates, reporting results ranging from $2 \%$ or less of the ingested starch in oats and diets based on rice and white bread, to $12 \%$ from cooked and cooled potatoes, and $75 \%$ from green bananas.

Langkilde \& Andersson $(1995 a, b)$ reported preliminary data on RS content in the EURESTA reference materials, as assessed in vivo using the ileostomy model. The results, expressed as $\mathrm{g}$ RS/ $100 \mathrm{~g}$ starting material were: raw potato starch $67 \cdot 9$, raw green banana flour 55.3, high amylose corn starch $43 \cdot 7$, and extruded retrograded high amylose corn starch $32 \cdot 1$. The pregelatinized potato starch control had only 0.8 and the cooked green banana flour $4.4 \mathrm{~g} \mathrm{RS} / 100 \mathrm{~g}$. Bean flakes from a different batch have been investigated previously by Schweizer et al. (1990), who found between $9 \cdot 0$ and $10.9 \%$ RS in that material (corresponding to about $20 \%$ of the starch).

\section{INTUBATION TECHNIQUES}

The quantitative assessment of ileal flow can be made in man after intestinal intubation using the technique of constant perfusion of a solution containing a non-absorbable marker (Flourié, 1992). Flourié et al. (1988) used this technique for measuring starch malabsorption 
from different diets. Volunteers are intubated with a triple lumen tube weighted by a mercury bag. When this has reached the colon, sampling of ileal contents takes place by aspiration $5 \mathrm{~cm}$ above the ileocaecal junction. A non-absorbable marker, polyethyleneglycol (PEG), is infused at a constant rate $25 \mathrm{~cm}$ proximal to the aspiration port, and the ileal flow is then assessed by estimating the dilution of the marker, which is presumed to be homogeneously mixed with the gut contents.

It can be argued that, with solid substrates such as RS, a liquid marker may not be suitable, and Flourié et al. (1988) found that PEG as a meal marker passed more rapidly than starch. However, the distance between the perfusion of the flow marker and the collection point $(25 \mathrm{~cm})$ could be optimized to minimize dissociation between liquid and solid phases and to obtain an optimal homogenization between the bolus and the marker. ${ }^{14} \mathrm{C}$-polyethyleneglycol and ${ }^{111}$ Indium $\left({ }^{111} \mathrm{In}\right)$ have been used as meal markers to control the calculation of the RS flow at the end of the small intestine. Faisant et al. (1992) showed that solid phase markers of rare earth metals were suitable as starch tracers, but the safety for humans is not fully clear. Faisant et al. (1992) tested a number of solid phase markers, and ${ }^{111}$ In was subsequently chosen as a meal marker to study one of the EURESTA reference materials, the raw banana flour (Faisant et al. $1995 a, c$ ). Using PEG as flow marker and ${ }^{111}$ In as meal marker, Faisant et al. $(1995 a, b)$ found that $19.3 \mathrm{~g}$ (range 16.7-21.5) RS was recovered from the end of the ileum after ingestion of $30 \mathrm{~g}$ raw banana flour, corresponding to $64 \%$ RS. These values should be compared with $15 \cdot 8(13 \cdot 3-19 \cdot 2) \mathrm{g}$ obtained in ileostomy studies using the same experimental meals (Langkilde et al. 1995). These limited data suggest that the intubation technique may provide somewhat higher estimates of RS than the ileostomy model, but more comparative studies are needed.

Another study with the intubation technique by Molis et al. (1992) showed 49.4 and $20.6 \%$ malabsorbed starch in lipid complexed and retrograded high amylose corn starch respectively. The in vitro content of RS, using the Berry method, was only 29.9 and $12.8 \%$ respectively, again indicating a higher than expected malabsorption using the intubation technique.

The advantage with the intubation technique is the possibility of studying individuals with an intact gut. It is, however, time consuming, invasive and expensive (Flourié, 1992). Furthermore, intubation reduces the intestinal residence time (Read et al. 1983). The importance of this effect for in vivo quantification of RS has not been investigated.

\section{ANIMAL MODELS}

There is a great need for appropriate animal models to study RS, as well as nutrition studies in general. For example, the numbers of subjects with ileostomies are decreasing owing to new surgical techniques creating continent pouches or rectal anastomoses. Animal models should have a digestive physiology and a habitual diet with a composition as close as possible to humans. The animal models should be evaluated in the same way as instrumental experimental techniques, and their advantages and weak points recognized.

Bach Knudsen (1992) reviewed five different animal models: antibiotic treated rats, caecectomized rats, colectomized rats, hydrogen excretion in rats, and ileum cannulated pigs regarding their usefulness for predicting starch digestibility in humans. The main advantages and disadvantages of these techniques are summarized in Table 3.

The antibiotic treated rat model was introduced by Eggum (1973), and has proved useful in studies on RS (Björck et al. 1986; Hansen et al. 1988). These authors used Nebacitin (a $1: 2$ mixture of Neomycin and Bacitracin) at $0.7 \%$ in the diet, which has been shown to reduce caecal and colonic microbial activity by $80-90 \%$, allowing estimation of ileal digestibility by analysis of faeces (for review, see Bach Knudsen, 1992). However, there are 


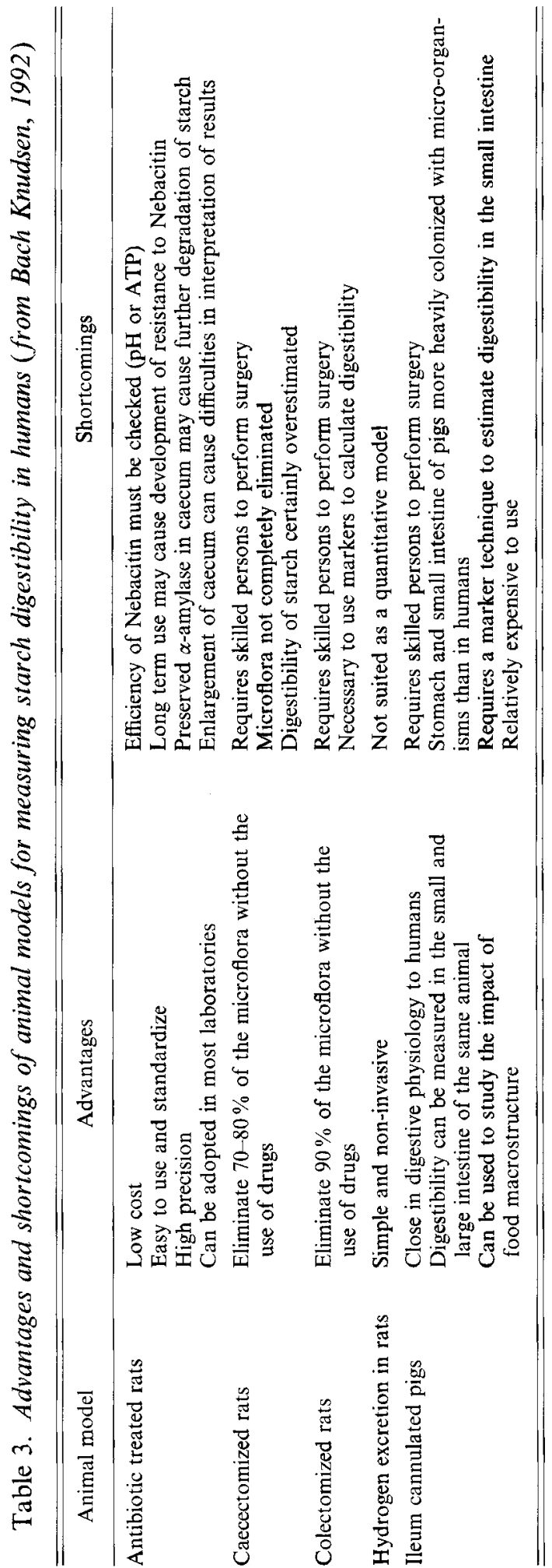


still significant concentrations of SCFA present in caecal contents in spite of the antibiotic treatment (Bach Knudsen et al. 1982). In practice, measurement of caecal $\mathrm{pH}$ provides a simple way of ensuring efficient microbial suppression. Typically, $\mathrm{pH}$ is close to 8 , as compared to 5-7 in rats not receiving any antibiotics (Björck \& Asp, 1992).

The antibiotic treatment has a number of effects in the gut, similar to those found in germ free rats. Notably, the caecum is enlarged two to six times with 50 -fold increase in total $\alpha$ amylase activity, compared with normal rats (Boisen et al. 1985). The mean transit time through the gut has been reported to increase from $32 \mathrm{~h}$ in controls to $47 \mathrm{~h}$ in antibiotic treated rats fed a diet containing $4 \%$ dietary fibre. At a higher level of fibre intake $(18 \%)$, the differences were less pronounced, i.e. $22 \mathrm{~h}$ and $25 \mathrm{~h}$ respectively. The prolonged retention of digesta together with the high amylase activity provide conditions for continued enzymic starch degradation in the colon. It is not known if degradation products are absorbed passively to any important extent.

For samples containing mainly the retrograded amylose type of RS, a number of studies (Björck et al. 1986, 1987; Björck \& Siljeström, 1992; Tovar et al. 1992; Granfeldt et al. 1993) have shown a very good correlation between RS estimates using the antibiotic treated rat and the total starch remaining in the dietary fibre residue prepared according to Asp et al. (1983). This was true also for three of the samples used in the initial EURESTA ring test (bean flakes, retrograded high amylose corn starch and corn flakes; Champ, 1992). On the other hand, the fourth sample, raw potato starch, had $23 \% \mathrm{RS}$ according to the rat model, but virtually none with the in vitro method owing to the gelatinization step included in it. The Berry method gave higher values for all the samples (Asp et al. 1992). When investigating the EURESTA reference samples, Ekwall et al. (1995a) found slightly lower in vivo RS estimates with the antibiotic treated rat model than in vitro with the Englyst or modified Berry methods for the processed samples (bean flakes, cooked green banana flour and extruded high amylose corn starch), while the antibiotic treated rat was surprisingly efficient in digesting the raw starches, especially that in raw green banana flour. Only about $10 \%$ of the raw banana starch passed through the gut of the antibiotic treated rats, but it should be noted that the sample had to be milled before incorporation in the diets, which might have damaged the starch granules to some extent. Of the raw potato starch, $42 \%$ was recovered in faeces, whereas Mathers et al. (1995) reported that $75 \%$ of raw potato starch was passing from the ileum in rats.

In conclusion, the antibiotic treated rat model seems to have good potential for ranking processed foods according to starch digestibility, but seems to underestimate the RS content especially in foods containing raw starch granules. The necessity of milling samples to get good control of the feed intake limits the possibility of assessing physically enclosed RSI.

Surgically modified rats, caecectomized or colectomized with an ileorectal anastomosis, have also been used in starch digestibility studies (Bach Knudsen et al. 1991; Hildenbrandt \& Marlett, 1991). In addition to the ethical concern, such rats have considerably decreased intestinal transit time and reduced digestibility of nutrients.

Hydrogen excretion in rats has been tried to follow fermentation of indigestible carbohydrates. It was concluded, however, that this technique could not be used to quantify fermentable substrates escaping digestion in the small intestine, but rather related to the rate at which substrates were delivered to the microorganisms (Hansen, 1989; Bach Knudsen, 1992).

Ileal cannulation of pigs is a well established technique that has contributed much to our understanding of digestive-absorptive events (Bach Knudsen, 1992). One main advantage is that the pig is closer physiologically to humans than are rodents. Microbial activity in the longer small intestine is, however, much more extensive than in man. 


\section{Rat feeding trial}

Gee et al. (1995) studied effects of RS on intestinal structure and function. The test materials were high amylose maize starch (Hylon VII), retrograded Hylon VII, 'Quenched' Hylon VII (gelatinized and rapidly cooled in liquid nitrogen to avoid retrogradation), and the extruded retrograded high amylose maize starch used as one of the EURESTA reference materials. These starches were given to normal rats as $20 \%$ of the diet for three weeks, and changes in the gut structure and function were followed. After the three weeks' feeding period, all the rats fed the RS-containing preparations had significantly higher faecal output. Liver mass and chemical composition were unchanged, and there was no evidence of changes in plasma lipid levels. Inconsistent effects were seen on crypt length in the jejunum. In the caecum crypt width was increased in the presence of RS. This may be associated with increased fermentative activity, evidenced by a fall in caecal $\mathrm{pH}$ of between 0.5 and 1.0 unit. Reductions in crypt cell proliferation rates were seen at various sites of the small and large intestine, whereas an increase was demonstrated in the caecum. It was concluded from these studies that the physiological effects of the consumption of RS were associated mainly with its fermentation in the large bowel. Rapid fermentation appears to favour an increase in crypt cell production rate in the caecum with a subsequent decrease at the colonic sites, whereas slower, persistent fermentation has less marked effect on the large bowel (Gee et al. 1995).

\section{EFFECTS ON GLYCAEMIC RESPONSE, SATIETY, AND THERMOGENESIS}

Since RS is not absorbed in the small intestine, it would not be expected to influence the postprandial hyperglycaemia after a meal, unless it interferes with the absorption of digestible starch or other nutrients. As pointed out by Raben et al. $(1994 a, b)$, a possible effect on satiety could be either negative due to decreased amount of absorbed carbohydrate, or positive if the RS had effects like some kinds of dietary fibre, for example on gastric emptying.

A joint study was performed within EURESTA on the effect of raw $v$. pregelatinized potato starch on postprandial glucose and hormonal responses, and on subjective sensations of hunger and satiety in healthy male volunteers (Raben et al. 1994a). The raw potato starch meal, containing $27.1 \mathrm{~g}$ RS and $13.6 \mathrm{~g}$ digestible starch, resulted in significantly lower postprandial glucose, lactate, insulin, gastric inhibitory polypeptide, glucagon-like peptide- 1 responses and a reduction in the satiating power of the meal, compared with the meal containing $46.5 \mathrm{~g}$ digestible starch (Raben et al. 1994b). De Roos et al. (1995) confirmed that $30 \mathrm{~g}$ RS 2 or RS 3/d for a week had little influence on appetite and food intake.

In the same experimental setup, Tagliabue et al. $(1995 a, b)$ and Heijnen et al. (1995b) found that the increase in postprandial energy expenditure was significantly greater after the test meal containing pregelatinized starch. The increase obtained after raw potato starch corresponded to its content of digestible starch, supporting the conclusion that RS has no thermogenic effect and does not influence the thermogenic response to digestible starch. Previously Ranganathan et al. (1994) reported that highly resistant starch (Lintner i.e. acid extracted high amylose corn starch) gave a slight but not significant glucose response when compared with cellulose. There was no thermogenic effect with the resistant starch or cellulose, nor any effect on the metabolic rate.

Granfeldt et al. (1995) studied the glycaemic response to arepa breads prepared from 
ordinary (25\% amylose) 'dent', or high amylose (70\% amylose) corn, in which $4 \%$ and $30 \%$ respectively of the starch was resistant (Granfeldt et al. 1993). The two products were given to healthy volunteers in equivalent amounts, either regarding total starch or digestible starch. In both cases, the glycaemic response after the dent product was significantly higher than after the high amylose product. This shows that the reduced glycaemia after the high amylose product was not simply related to a decreased proportion of digestible starch, but rather to a reduced enzymic accessibility of the digestible starch in the presence of RS (Granfeldt et al. 1995).

\section{EFFECTS ON PLASMA LIPIDS}

Dietary fibre of the soluble, viscous type has a well documented effect in lowering the low density lipoprotein cholesterol level. The possibility of such effects of RS has been studied in animal and human experiments, and by measuring effects on sterol excretion from the small intestine.

De Deckere et al. (1993) found that high amylose corn starch lowered the blood cholesterol level in rats by $10-15 \%$, which is in line with several other studies (Sacquet et al. 1983; Mathé et al. 1993). De Deckere et al. (1993) also found significant reductions in triacylglycerol levels. In a recent study De Deckere et al. (1995) tested different types of RS in rats. They found no effect on total serum cholesterol but again reductions in the triacylglycerol concentration. An earlier study by Demigné \& Rémésy (1982) showed reductions in both cholesterol and triacylglycerols by feeding raw potato starch to rats, which was confirmed in a more recent study from the same group (Morand et al. 1994).

Thus, several animal studies have shown that RS may reduce serum lipid levels. In order to investigate mechanisms involved in this effect, De Deckere and colleagues studied faecal sterol excretions in rats (De Deckere et al. 1995; Verbeek et al. 1995). There was no effect of RS on the liver cholesterol content, but the serum total bile acids concentration increased, suggesting an increased enterohepatic bile acid pool. There was no effect of RS on caecal content or faecal excretion of neutral sterols. Total bile acid excretion, on the other hand, increased and this may be a mechanism for the cholesterol reducing effect. There was also an increased ratio of primary over secondary bile acids. In a human ileostomy study, fully reported by Ekwall et al. (1995b), Langkilde \& Andersson (1992) found a significantly lower cholic acid excretion after retrograded high amylose corn starch than after the pregelatinized ordinary corn starch used as a control, but there was no effect on cholesterol or chenodeoxycholic acid excretion.

With this background, possible effects of RS on plasma lipids in man have been investigated. In a pilot study by Olesen et al. (1995) there was no significant effect on blood cholesterol concentration by $50 \mathrm{~g} / \mathrm{d}$ of raw potato starch or high amylose corn starch, but it was stressed that the baseline values fluctuated considerably, masking any minor effects. A more comprehensive study recently performed by Heijnen et al. (1996) in healthy volunteers indicated that there was no significant effect of supplementing $30 \mathrm{~g} / \mathrm{d}$ RS 2 or RS 3 to the diet on fasting levels of serum total cholesterol, high density lipoprotein cholesterol, low density lipoprotein cholesterol, or triacylglycerols. Ranganathan et al. (1994) observed, within an acute study, that a high amylose corn starch had no effect on blood non-esterified fatty acids (NEFA) and NEFA oxidation comparable with cellulose. However, a lowering of blood NEFA was observed by Faisant et al. (1994) in two subjects with subnormal levels of fasting NEFA. This observation has to be confirmed in a much higher number of subjects.

In conclusion, RS does not seem to have major effects on plasma lipid levels in healthy, 
normolipidaemic humans. The effects demonstrated in animals probably require higher doses of RS than is feasible in practice in a human diet.

\section{EFFECTS ON MINERAL BALANCE}

Resistant starch type 2 (resistant granules), but not retrograded RS (type 3), increased apparent calcium absorption in rats by enhancing the solubility of these minerals in ileal and caecal digesta, probably by decreasing the luminal $\mathrm{pH}$ through fermentation (Schulz et al. 1993). To study possible effects on mineral balance in man, Heijnen et al. (1995a) gave RS, $30 \mathrm{~g} / \mathrm{d}$, either raw or pregelatinized high amylose corn starch, in supplements to 24 apparently healthy male volunteers. The apparent absorptions of $\mathrm{Ca}, \mathrm{Mg}$ and $\mathrm{P}$ were not affected by RS supplementation. The authors mentioned three possible reasons for the discrepancies between animal and human experiments in mineral absorption: (1) a possible difference in fermentation efficiency between man and rat; (2) the use of a different kind of RS in the rat study, that may be less resistant to fermentation; and (3) the fact that rats consumed on average $17 \mathrm{~g}$ RS per $\mathrm{kg}$ body weight daily, compared with only $0.4 \mathrm{~g}$ in the human study (Heijnen et al. 1995a).

\section{PHYSIOLOGICAL EFFECTS IN THE LARGE BOWEL}

Before the inception of the EURESTA programme, there were few studies on the effects of RS on large bowel function (for review, see e.g. British Nutrition Foundation, 1990; Livesey, 1992; Annison \& Topping, 1994). Indirectly, the fact that faecal bulking of foods containing dietary fibre is more pronounced than is expected from their content of NSP indicates a 'carbohydrate gap' (Stephen 1991) that could be filled by RS. Cummings \& Macfarlane (1991) postulated that 8-40 g enzyme resistant starch could enter the large bowel daily on a British diet.

The studies on large bowel effects of RS within EURESTA were summarized by Cummings et al. (1995). Owing to the insolubility and absence of hydrophilic and viscosity increasing properties of RS, physiological effects could be expected to originate primarily from its fermentation in the large bowel. Some early studies show that starches from a number of sources are fermented at various rates, and that fermentation products include hydrogen, $\mathrm{CO}_{2}$, acetate, propionate, butyrate and lactate (Englyst \& Macfarlane, 1986; Macfarlane \& Englyst, 1986; Wyatt \& Horn, 1988). The possibility that RS might be an especially good substrate for butyrate production, first suggested from in vitro studies by Englyst et al. (1987), increased the interest in starch as a fermentation substrate in the human colon.

Animal studies mainly in rats had shown a different extent of fermentation of RS from various sources (e.g. Faulks et al. 1989), and evidence for effects on cell proliferation were present (Demigné \& Rémésy, 1982; Gee et al. 1991). The use of breath hydrogen excretion as an indirect measure of starch fermentation is reviewed above. Starch infusions into the colon were used by Flourié et al. (1986), who demonstrated lowering of $\mathrm{pH}$ and production of SCFA as a result of the fermentation.

The working group on large bowel effects of RS agreed that the priorities were to determine the amount of RS reaching the large intestine, and to study its fermentation using both in vitro and in vivo methods. Secondly, the impact of fermentation on colonic luminal events, epithelial cell physiology, and metabolism at other sites in the body required further investigation, e.g. regarding effects on faecal composition including bile acids, SCFA and nitrogen metabolism, with special emphasis on factors of importance in colonic carcinogenesis (Cummings et al. 1995). Two joint initiatives were set up: 
development of a simple standardized in vitro method for fermentation in the laboratory using human faecal inocula, and studies on the impact of RS on cellular proliferation in the gut.

\section{FERMENTATION AND RING TEST FOR ITS MEASUREMENT IN VITRO}

Previous studies of carbohydrate fermentation by human faecal flora in vitro have used different conditions - medium, buffers, inoculum size and fermentation time - which make comparison between studies difficult (Cummings et al. 1995). A standard in vitro test was therefore devised within EURESTA and tested in eight laboratories with 40 individual faecal inocula. The results are summarized by Cummings et al. (1995) and reported fully by Edwards et al. (1996).

The starches studied in this ring test were pregelatinized potato starch $(0 \% \mathrm{RS})$, raw potato starch (54\% RS), highly refined retrograded amylose $(60 \%)$ and glassy pea starch $(5.8 \% \mathrm{RS})$. Faeces from healthy adult donors were processed within $1 \mathrm{~h}$ of passage and made into a $32 \%$ slurry with phosphate buffer $\mathrm{pH} 6 \cdot 5$. This was then diluted in equal volumes with phosphate buffer containing the starch to be tested. Anaerobic conditions were maintained as far as possible. In general, the agreement between laboratories was regarded as good for both SCFA production and starch remaining at various time intervals during the $24 \mathrm{~h}$ experiment, with clear discrimination of fermentation rate between the various starches under investigation. Retrograded amylose was slowly fermented, which may have implications for its action in the human colon. There were no differences between methane and non-methane producers in starch fermentation nor in the stoichiometry of fermentation products (Cummings et al. 1995).

A number of studies point to the SCFA pattern from RS breakdown being different from that of NSP. The preferential production of butyrate in the fermentation of RS, demonstrated in vitro, has been confirmed in human faeces (Scheppach et al. 1988; Van Munster et al. 1994) but not in animal studies (Mathers \& Smith, 1993; Berggren et al. 1995). The yield of SCFA from starch is relatively high, approaching $60 \%$ on a weight basis. As a consequence, the energy from RS may be higher than from NSP which gave a lower yield of SCFA (Cummings et al. 1995).

\section{ANIMAL MODELS}

As mentioned above, animal models (rats and pigs) have been used to quantify the starch flow to the large bowel, i.e. for determining the amount of RS. The fermentation pattern has been studied by SCFA analyses of caecal contents and faeces. Starch reaching the caecum is usually readily fermented, and the retrograded type of RS (RS 3) can usually not be detected in faeces (Björck et al. 1987; Goodlad \& Mathers, 1992; Key \& Mathers, 1993). Although it has been reported that starch fermentation yields increased proportions of butyrate, Mathers \& Smith (1993) found that with high intakes of raw potato starch the proportion of butyrate declined, possibly because of an effect of prolonged caecal transit time (Mathers \& Dawson, 1991).

The fate of absorbed carbon from digestion and/or fermentation of starch was investigated by feeding rats a single dose $(20 \mathrm{mg})$ of either ${ }^{14} \mathrm{C}$-retrograded ${ }^{\circ}{ }^{14} \mathrm{C}$ gelatinized bean starch. At 3 and $18 \mathrm{~h}$ after dosing with the retrograded starch, most of the radioactivity incorporated into the animal's tissue was recovered in carcass, pelt and liver. The radioactivity was mainly incorporated into protein, especially into glutamic acid and aspartic acid (Abia et al. 1993, 1995, 1996; Cummings et al. 1995). 


\section{CELL PROLIFERATION}

In a human feeding study with healthy volunteers consuming $45 \mathrm{~g}$ raw high amylose corn starch, the faecal output of butyrate increased, both in absolute amounts and as a proportion of total SCFA (Van Munster et al. 1994). The concentration of deoxycholic acid in faecal water fell as did faecal water toxicity as measured by exposing colonic cell cultures to faecal water extracts; the latter could be a consequence of reduced $\mathrm{pH}$ due to the fermentation. Crypt cell production rates obtained from rectal biopsies showed reduced labelling index, indicative of suppressed cell proliferation (reviewed by Cummings et al. 1995).

\section{BOWEL HABIT}

The major end products of starch fermentation are SCFA and bacterial cells. Livesey (1995) estimated from unpublished data on rats (Mathers) and humans (Englyst \& Cummings) that bacterial dry matter production was $\sim 250 \mathrm{~g} / \mathrm{kg}$ starch fermented. This would be expected to contribute to the faecal bulk because of the high intracellular water content of bacteria.

A number of studies on the effect of RS on bowel habit have been reported but findings are somewhat inconsistent. There was little effect on colonic function and no significant difference in faecal bulk when comparing a diet with breakfast cereals providing $10 \mathrm{~g} / \mathrm{d} \mathrm{RS}$ $v$. another cereal providing only $1 \mathrm{~g} / \mathrm{d}$ (Tomlin \& Read, 1990). Shetty \& Kurpad (1986), on the other hand, demonstrated an increased faecal bulking by increased starch intake. A number of studies have shown no effect on transit time (for review see Cummings et al. 1995). Obviously, more studies are needed on the faecal bulking effect of various types of $\mathrm{RS}$ in man.

\section{BILE ACID METABOLISM}

Van Munster et al. (1995) demonstrated, using an in vitro human faecal incubation system, that addition of fermentable substrate in the form of lactulose or RS (Hylon VII) can inhibit the conversion of primary into secondary bile acids and decrease the concentration of soluble deoxycholic acid. This secondary bile acid has been shown to be cytotoxic. In the study by Van Munster et al. (1994) in which $45 \mathrm{~g} / \mathrm{d}$ of raw high amylose corn starch with about $60 \%$ resistant starch was given to healthy volunteers for 2 weeks, the fraction of secondary bile acids was decreased from $93 \%$ to $82 \%$, and the cytotoxic bile acids in the caecal water fraction decreased significantly (Cummings et al. 1995).

\section{CALCULATING THE ENERGY VALUE OF RESISTANT STARCH IN MAN}

Livesey (1995) reviewed the energy value of RS in man, noting the fact that whereas the amounts of energy made available from NSP and sugar alcohols have been reasonably well defined, the amounts from RS have received little attention so far. The working group on energy chose a model established for unavailable carbohydrate (NSP and RS) (British Nutrition Foundation, 1990):

$$
E=(1-A-B-C) \times D \times G \times H .
$$

In this model, $E$ was the energy value, $A$ was the efficiency of microbial mass production:, $B$ was the efficiency of combustible gas production, i.e. $\mathrm{H}_{2}$ and $\mathrm{CH}_{4}, C$ was the heat of fermentation $(\mathrm{kJ} / \mathrm{kJ}$ of starch fermented), $D$ was the extent of fermentation of $\mathrm{RS}$ in the 
large intestine, $G$ was the yield of ATP per kJ SCFA produced in fermentation as a fraction of the ATP that would have been produced had the energy absorbed been glucose, and $H$ was the heat of combustion of resistant starch, $4.2 \mathrm{kcal}$ or $17.5 \mathrm{~kJ} / \mathrm{g}$. The aim was to establish reasonable numerical values for the unknowns for RS.

Based on a number of studies, e.g. Livesey et al. (1990), reviewed by Livesey (1995), the efficiency of microbial biomass production (A in the model) was estimated to be approximately $0.3 \mathrm{~kJ} / \mathrm{kJ}$ RS fermented. Regarding B, no quantitative experiments have been reported measuring how much energy might be lost as combustible gases. Livesey (1992) and Livesey et al. (1993) reviewed all types of carbohydrates and sugar alcohols investigated so far, concluding that this loss is $\leqslant 5 \%$ of all the carbohydrate energy fermented. A similar figure for RS is supported by a number of in vitro experiments reviewed by Livesey (1995).

As mentioned previously, human studies (Raben et al. 1994a, b; Heijnen et al. 1995; Tagliabue et al. 1995a,b) have indicated that the resistant fraction of raw potato starch is not thermogenic. These studies, however, consider only the non-fermentative phase of intestinal degradation. A number of preliminary studies, reviewed by Livesey (1995), indicate that the thermogenic effect of the fermentative degradation of carbohydrates is of the order of $3 \mathrm{~kJ} / \mathrm{g}$. While the range of RS investigated and the number of observations in adults are limited, it did not appear that RS would be more thermogenic than expected, and that the terms $\mathrm{C}$ and $\mathrm{G}$ would together account for about $20 \%$ of the energy in starch fermented, i.e. $3 \mathrm{~kJ} / \mathrm{g}$.

There is evidence that RS does not alter the absorption of other energy yielding nutrients. With increasing intake by rats of RS from raw potato starch, Mathers et al. (1995) reported a progressive increase in dry matter lost from the terminal ileum, which paralleled the increase in RS. In ileostomates fed RS from raw green banana, raw potato and retrograded high amylose corn starch, the ileal losses of starch contributed 87, 85 and $114 \%$ respectively of the increase in dry matter lost from the ileum (Langkilde et al. 1995). These data indicate that the model does not need inclusion of a term for changes in macronutrient absorption due to RS ingestion (Livesey, 1995).

The numerical values suggested for the constants, i.e. $A=0 \cdot 30, B=0 \cdot 05, C+G=0 \cdot 20$, are similar to those proposed for unavailable carbohydrates in general (British Nutrition Foundation, 1990; Livesey, 1992). Substituting these values in the model gives a value of $8.8 \mathrm{~kJ} / \mathrm{g}$ for fully fermentable RS. This value is expected to decrease with decreasing fermentability, D.

\section{CONCLUDING REMARKS AND FURTHER RESEARCH NEEDS}

RS has been established as one of the main sources, together with NSP and oligosaccharides, of carbohydrate substrate for the colonic microflora, and thereby is one determinant of large bowel function in man. Physical enclosure, ungelatinized starch granules of the B-type, and retrogradation are the main reasons for resistance. The rate and completeness of fermentation of RS varies depending on the source and heat treatments used. This creates the possibility of influencing the site of RS fermentation in the large bowel through appropriate choice of raw material and processing conditions.

Methods for the determination of RS are designed to estimate the residue after treatment of the sample with enzymes simulating normal starch digestion in the small intestine. Two main approaches for determination of total RS have been evaluated. A critical step is simulation of the normal disintegration of foods by chewing in order to recover physically enclosed starch. 
Some animal experiments have shown cholesterol lowering properties, but such effects have not been confirmed in normolipidaemic man with doses of RS that can be readily incorporated in a diet and tolerated. However, hyperlipidaemic subjects have not yet been studied. RS did not seem to affect postprandial energy metabolism and had no effect on mineral balance in humans. The caloric value has been estimated as $\sim 2 \mathrm{kcal} / \mathrm{g}$. There is evidence for the production of a comparatively high proportion of butyrate from the fermentation of starch. This and other SCFA may have health promoting effects on colonic epithelial cells through effects on the conversion of bile acids, nitrogen metabolism and faecal bulk.

The effects of different types of RS should be further explored, regarding site of fermentation, fermentation products, effects on cell proliferation, colonic nitrogen metabolism and other factors of importance for colonic health, especially cancer risk.

The current intake of RS in different population groups seems to be rather low $(\sim 4 \mathrm{~g} / \mathrm{d})$ but this should be investigated further. In view of the various physiological effects discussed above, production of foods designed to contain RS with optimal physiological properties seems to have a considerable health benefit potential.

The skilful editorial assistance of Ms Riet Hoogkamer is gratefully acknowledged.

\section{APPENDIX}

In 1990, the Commission of the European Communities approved a concerted action project within its Food-Linked Agro-Industrial Research programme, entitled 'Physiological Implications of the Consumption of Resistant Starch in Man' (FLAIR Concerted Action No. 11, COST 911). The project, named by the acronym EURESTA, involved up to 40 research groups from 11 European countries and lasted four years.

Proceedings from the second plenary meeting held in 1991 have been published (Asp, $1992 a$ ), giving a state of the art description at the beginning of the project. The present review focuses on the work carried out by participants in the project since then, and is based especially on a final publication from the project (Asp et al. 1995), containing working group reports and summaries of presentations at the last plenary meeting in 1994. The review has been organized according to the working group structure of the project.

\section{Participants}

Belgium

Dr F. Bornet, Eridania Béghin-Say, Nutrition and Health Service, Vilvoorde Research \& Development Centre, Havenstraat 84,1800 Vilvoorde.

Professor J. Delcour/Dr R. Eerlingen, Faculty of Agriculture and Applied Biological Sciences, Research Unit Food Chemistry, Kardinaal Mercierlaan 92, 3001 Leuven.

Dr P. Dysseler/Ing. D. Hoffem, Food Science and Technology Department, CERIA - Institut Meurice, Avenue E. Gryzon 1, 1070 Brussels.

\section{Denmark}

Professor A. Astrup/Dr A. B. Raben, Research Department of Human Nutrition, The Royal Veterinary and Agricultural University, Rolighedsvej 30, 1958 Frederiksberg C.

Dr K. E. Bach Knudsen, National Institute of Animal Science, Department of Animal Physiology and Biochemistry, P.O. Box 39, 8830 Tjele.

Dr B. B. Jensen, National Institute of Animal Science, Department of Animal Physiology and Biochemistry, P.O. Box 39, 8830 Tjele.

Professor E. Gudmand-Høyer*/Dr J. J. Rumessen/Dr M. Olesen, Department of Medical Gastroenterology, Gentofte University Hospital, Niels Andersensvej 65, 2900 Hellerup.

Dr A. A. Olsen, Novo Nordisk Biolabs, Enzyme-chemistry Laboratory, Novo Allé, 2880 Bagsvaerd.

Dr A. Sørensen, National Food Agency, Institute for Food Chemistry and Nutrition, Mørkhøj Bygade 19, 2860 Søborg. 


\section{France}

Dr M. Champ*, Applied Technology and Nutrition, I.N.R.A., P.O. Box 1627, 44316 Nantes Cedex 03.

Dr P. Colonna, Applied Technology and Nutrition, I.N.R.A., P.O. Box 527, 44026 Nantes Cedex 03.

Dr B. Flourié, INSERM U 290, 107 Rue du Fb Saint-Denis, 75010 Paris.

Professor M. Krempf, CHR of Nantes, Clinique d'Endocrinologie Maladies Métaboliques, Nutrition, P.O. Box 1005, 44035 Nantes Cedex 01.

\section{Germany}

Dr H. Anger/Dr H.-J. Zunft/Dr G. Stoof, Deutsches Institut für Ernährungsforschung, Potsdam-Rehbrücke, Arthur-Scheunert-Allee 114-116, 1505 Bergholz-Rehbrücke.

Dr E. Rabe, Federal Centre for Cereal, Potato and Lipid Research in Detmold and Münster, P.O. Box 1354, 32703 Detmold.

Italy

Dr C. Lintas, Istituto Nazionale della Nutrizione, Via Ardeatina, 546, 00178 Rome.

Dr A. Rivellese, Internal Medicine and Metabolic Disease Institute, Via S. Pansini 5, 80131 Naples.

Dr A. Tagliabue/Professor Dr E. Lanzola, Department of Human Nutrition, University of Pavia, Via A. Bassi, 21, 27100 Pavia.

\section{The Netherlands}

Dr J. M. M. van Amelsvoort*/Dr E. A. M. de Deckere, Unilever Research Laboratory, P.O. Box 114, 3130 AC Vlaardingen.

Professor A. C. Beynen, Department of Laboratory Animal Science, State University Utrecht, P.O. Box 80.116, 3508 TD Utrecht.

Professor J. G. A. J. Hautvast*/Dr P. Deurenberg/Dr M.-L. Heijnen, Department of Human Nutrition, Wageningen Agricultural University, Bomenweg 2, 6703 HD Wageningen.

Dr F. Nagengast/Dr I. van Munster, Department of Gastroenterology, University Hospital, P.O. Box 9101,6500 HB Nijmegen.

Dr J. Veenstra, Hercules European Research Centre, P.O. Box 414, 3770 AK Barneveld

\section{Norway}

Dr W. Frølich, Nutrition Research Department, Norwegian Dairies Association, P.O. Box 9051, Gronland, 0133 Oslo 1.

\section{Spain}

Dr F. Saura-Calixto*/Dr L. Bravo, Instituto del Frio, C.S.I.C., Departamento Metabolismo y Nutrición, Ciudad Universitaria, 28040 Madrid.

\section{Sweden}

Professor N.-G. Asp*/Dr 1. Björck/H. Ekwall, M.Sc., Chemical Centre, Department of Applied Nutrition and Food Chemistry, University of Lund, P.O. Box 124, 22100 Lund.

Professor H. Andersson/Dr A. M. Langkilde, Department of Clinical Nutrition, Gothenburg University, Annedalsklinikerna, 41345 Gothenburg.

\section{Switzerland}

Dr P. Würsch*, Nestlé Research Centre, Nestec Ltd, Vers-chez-les-Blanc, P.O. Box 44, 1000 Lausanne 26.

\section{United Kingdom}

Dr J. Cummings*/Dr H. N. Englyst, Dunn Clinical Nutrition Centre, Hills Road, Cambridge CB2 2DH.

Dr M. Eastwood/Dr R. Abia, Gastro-Intestinal Unit, Western General Hospital, Crewe Road, Edinburgh EH4 $2 \mathrm{XU}$.

Dr C. A. Edwards, Department of Human Nutrition, Yorkhill Hospitals, Glasgow G3 8SJ.

Dr I. T. Johnson/Mrs J. M. Gee, Nutrition Diet \& Health Department, BBSRC Institute of Food Research, Norwich Laboratory, Colney Lane, Norwich NR4 7UA.

Dr G. Livesey/Mr R. Faulks, Nutrition \& Food Quality, BBSRC Institute of Food Research, Norwich Laboratory, Colney Lane, Norwich NR4 7UA.

Professor J. C. Mathers, Department of Biological and Nutritional Sciences, The University of Newcastle upon Tyne, Newcastle upon Tyne NEI 7RU.

Dr S. G. Ring, BBSRC Institute of Food Research, Norwich Laboratory, Colney Lane, Norwich NR4 7 UA

Dr I. Rowland/Dr Corinne Rumney, BIBRA Toxicology International, Department of Microbiology, Woodmansterne Road, Carshalton, Surrey SM5 4DS.

Dr J. Tomlin, Centre for Human Nutrition, Northern General Hospital, Herries Road, Sheffield S5 7AU.

* Member of the Project Management Group. 


\section{REFERENCES}

Abia, R., Buchanan, C. J., Saura-Calixto, F. \& Eastwood, M. A. (1993). Structural changes during the retrogradation of legume starches modify the in vitro fermentation. Journal of Agricultural and Food Chemistry 41, $1856-1863$.

Abia, R., Fry, S. \& Eastwood, M. A. (1995). A comparison of U- ${ }^{14}$ C-retrograded and U- ${ }^{14}$-gelatinised bean starch metabolism in the rat. In Asp et al. (1995), pp. 63-64.

Abia, R., Fry, S. \& Eastwood, M. A. (1996). Metabolic transformations of ${ }^{14}$ C-retrograded and U- ${ }^{14} \mathrm{C}$-gelatinised bean starch in rat liver and carcass. Journal of Agricultural and Food Chemistry, in press.

Anderson, I. H., Levine, A. S. \& Levitt, M. D. (1981). Incomplete absorption of the carbohydrate in all-purpose wheat flour. New England Journal of Medicine 304, 891-892.

Andersson, H. (1992). The ileostomy model for the study of carbohydrate digestion and carbohydrate effects on sterol excretion in man. European Journal of Clinical Nutrition 46, supplement 2, S69-S76.

Andersson, H. (1995). The ileostomy model - an update with emphasis on the role of a possible adaptation. In Asp et al. (1995), pp. 25-27.

Andersson, H., Bosaeus, I., Ellegård, L., Hallgren, B., Hultén, L. \& Magnusson, O. (1984a). Comparison of an elemental and two polymeric diets in colectomized patients with or without intestinal resection. Clinical Nutrition 3, 183-189.

Andersson, H., Hultén, L., Magnusson, O. \& Sandström, B. (1984b). Energy and mineral utilization from a peptide-based elemental diet and a polymeric enteral diet given to ileostomists in the early postoperative course. Journal of Parenteral and Enteral Nutrition 8, 497-500.

Annison, G. \& Topping, D. L. (1994). Nutritional role of resistant starch: chemical structure vs. physiological function. Annual Review of Nutrition 14, 297-320.

Asp, N.-G. (1992a). Resistant Starch. Proceedings of the 2nd plenary meeting of EURESTA: European Flair Concerted Action No. 11 (COST 911). Physiological Implications of the Consumption of Resistant Starch in Man. European Journal of Clinical Nutrition 46, Supplement 2, $148 \mathrm{pp}$.

Asp, N.-G. (1992b). Preface: Resistant Starch. Proceedings of the 2 nd plenary meeting of EURESTA : European Flair Concerted Action No. 11 on Physiological Implications of the Consumption of Resistant Starch in Man. European Journal of Clinical Nutrition 46, Supplement 2, S1.

Asp, N.-G. \& Björck, I. (1992). Resistant starch. Trends in Food Science and Technology 3, 111-114.

Asp, N.-G., Gudmand-Høyer, E., Andersen, B., Berg, N.-O. \& Dahlkvist, A. (1975). Distribution of disaccharidases, alkaline phosphatase, and some intracellular enzymes along the human small intestine Scandinavian Journal of Gastroenterology 10, 647-651.

Asp, N.-G., Johansson, C.-G., Hallmer, H. \& Siljeström, M. (1983). Rapid enzymatic assay of insoluble and soluble dietary fiber. Journal of Agricultural and Food Chemistry 31, 476-482.

Asp, N.-G., Tovar, J. \& Bairoliya, S. (1992). Determination of resistant starch in vitro with three different methods, and in vivo with a rat model. European Journal of Clinical Nutrition 46, Supplement 2, S117-S119.

Asp, N.-G., Van Amelsvoort, J. M. M. \& Hautvast, J. G. A. J. (Eds) (1995). Proceedings of the Concluding Plenary Meeting of EURESTA, including the final reports of the working groups, 204 pp. Wageningen: EURESTA. ISBN 90-9008390-1.

Bach Knudsen, K. E. (1992). Methodological aspects of in vivo methods for measuring of starch digestibility: animal models. In Methodological Aspects of in vivo Methods for Measurement of Starch Digestibility. EURESTA Report, pp. 40-57 [E. Gudmand-Høyer, editor]. Vedbæk, Denmark.

Bach Knudsen, K. E., Agergaard, N. \& Olesen, H. P. (1991). Effect of caecectomy and transit time on digestibility of plant polysaccharides and of amino acids in rats. Journal of Animal Physiology and Animal Nutrition 66, 190-203.

Bach Knudsen, K. E., Wolstrup, J. \& Eggum, B. O. (1982). The nutritive value of botanically defined mill fractions of barley. 2. The influence of hind-gut microflora in rats on digestibility of protein and energy of endosperm and husk of Bomi and M-1508. Zeitschrift für Tierphysiologie, Tierernährung und Futtermittelkumde 48, 276-287.

Berggren, A. M., Björck, I. M. G., Nyman, M. G. L. \& Eggum, B. O. (1995). Short-chain fatty acid content and $\mathrm{pH}$ in caecum of rats fed various sources of starch. Journal of the Science of Food and Agriculture 68, $241-248$.

Berry, C. S. (1986). Resistant starch: formation and measurement of starch that survives exhaustive digestion with amylolytic enzymes during the determination of dietary fibre. Joumal of Cereal Science 4, 301-314.

Björck, I. \& Asp, N.-G. (1992). Balance experiments in Nebacitin-treated rats. In Methodological Aspects of In Vivo Methods for Measurement of Starch Digestibility. EURESTA Report, pp. 35-39 [E. Gudmand-Høyer, editor]. Vedbæk, Denmark.

Björck, I., Nyman, M., Pedersen, B., Siljeström, M., Asp, N.-G. \& Eggum, B. O. (1986). On the digestibility of starch in wheat bread - studies in vitro and in vivo. Journal of Cereal Science 4, 1-11.

Björck, I., Nyman, M., Pedersen, B., Siljeström, M., Asp, N.-G. \& Eggum, B. O. (1987). Formation of enzyme resistant starch during autoclaving of wheat starch: studies in vitro and in vivo. Journal of Cereal Science 6 , $159-172$

Björck, I. M. E. \& Siljeström, M. A. (1992). In-vivo and in-vitro digestibility of starch in autoclaved pea and potato products. Journal of the Science of Food and Agriculture 58, 541-553. 
Boisen, S., Agergaard, N., Rotenberg, S. \& Kragelund, Z. (1985). Effects of gut flora on intestinal activities of trypsin, chymotrypsin, elastase and amylase in growing rats fed purified diets with cellulose, pectin or sand. Zeitschrift für Tierphysiologie, Tierernährung und Futtermittelkunde 53, 245-254.

Bosaeus, I. G. \& Andersson, H. B. (1987). Short-term effect of two cholesterol-lowering diets on sterol excretion in ileostomy patients. American Journal of Clinical Nutrition 45, 54-59.

Botham, R. L., Cairns, P., Morris, W. J. \& Ring, S. G. (1995). Physicochemical characterisation of resistant starch in ileostomy effluent. In Asp et al. (1995), pp. 71-72.

Bravo, L., Goñi, I., Fernandez-Martin, F. \& Saura-Calixto, F. (1995). Effect of deep-fat frying on resistant starch formation in potato chips. In Asp et al. (1995), pp. 73-76.

British Nutrition Foundation (1990). Complex Carbohydrates in Foods. The report of the British Nutrition Foundation's Task Force. London, Chapman and Hall.

Champ, M. (1992). Determination of resistant starch in foods and food products: interlaboratory study. European Journal of Clinical Nutrition 46, Supplement 2, S51-S62.

Champ, M. (1995). EURESTA Working Group I: Definition, analysis, physical and chemical characterization of RS. In Asp et al. (1995), pp. 1-14.

Champ, M. \& Faisant, N. (1995). Overview of available methods for determination of resistant starch within EURESTA. In Recent Progress in the Analysis of Dietary Fibre (Proceedings of a Workshop, 1994), pp. 45-51. Copenhagen. COST 92 Physiological and Metabolic Effects of Dietary Fibre in Food.

Champ, M. \& Faisant, N. (1996). 11-Resistant starch. Proceedings of the Third International Workshop on 'Carbohydrates as Organic Raw Materials', vol. III, pp. 189-215. [H. van Bekkum, H. Röper and A. G. J. Voragen, editors]. Wageningen. In press.

Christl, S. U., Murgatroyd, P. R., Gibson, G. R. \& Cummings, J. H. (1992). Production, metabolism, and excretion of hydrogen in the large intestine. Gastroenterology 102, 1269-1277.

Colonna, P., Leloup, V. \& Buléon, A. (1992). Limiting factors of starch hydrolysis. European Journal of Clinical Nutrition 46, Supplement 2, S17-S32.

Cummings, J. H. (1992). Report of discussion on the ileostomy model. In Methodological Aspects of In Vivo Methods for Measurement of Starch Digestibility. EURESTA Report, pp. 19-22 [E. Gudmand-Høyer, editor]. Vedbæk, Denmark.

Cummings, J. H., Edwards, C., Gee, J., Nagengast, F. \& Mathers, J. (1995). EURESTA Working Group III B Physiological effects of resistant starch in the large bowel. In Asp et al (1995), pp. 38-55.

Cummings, J. H. \& Englyst, H. N. (1991). Measurement of starch fermentation in the human large intestine Canadian Journal of Physiology and Pharmacology 69, 121-129.

Cummings, J. H. \& Macfarlane, G. T. (1991). The control and consequences of bacterial fermentation in the human colon. Journal of Applied Bacteriology 70, 443-459.

De Deckere, E. A. M., Kloots, W. J. \& Van Amelsvoort, J. M. M. (1993). Resistant starch decreases serum total cholesterol and triacylglycerol concentrations in rats. Journal of Nutrition 123, 2142-2151.

De Deckere, E. A. M., Verbeek, M. J. F., Van Amelsvoort, J. M. M., Tijburg, L. B. M. \& Beynen, A. C. (1995). Resistant starch and faecal sterol excretion in rats. In Asp et al. (1995), pp. 78-81.

Demigné, C. \& Rémésy, C. (1982). Influence of unrefined potato starch on cecal fermentations and volatile fatty acid absorption in rats. Journal of Nutrition 112, 2227-2234.

De Roos, N., Heijnen, M.-L., De Graaf, C., Woestenenk, G. \& Hobbel, E. (1995). Resistant starch has little effect on appetite, food intake and insulin secretion of healthy young men. European Journal of Clinical Nutrition 49. 532-541.

Dysseler, P. \& Hoffem, D. (1995a). Ring test 1993-1994 for total and resistant starch determination: results and discussion. In Asp et al. (1995), pp. 87-94.

Dysseler, P. \& Hoffem, D. (1995b). Comparison between Englyst's method and Berry's modified method on 20 different starchy foods. In Asp et al. (1995), pp. 95-98.

Dysseler, P. \& Hoffem, D. (1995 c). Estimation of resistant starch intake in Europe. In Asp ef al. (1995), pp. 84-86.

Edwards. C. A., Gibson, G., Champ, M., Nagengast, F., Quehl, A., Jensen, B. B., Rumney, C. \& Mathers, J. C. (1996). In vitro method for the quantification of fermentation of starch by human faecal bacteria. Journal of the Science of Food and Agriculture 71, in press.

Eerlingen, R. (1994). Formation, Structure and Properties of Enzyme Resistant Starch. PhD thesis. Katholieke Universiteit, Leuven, Belgium.

Eerlingen, R. C., Cillen, G. \& Delcour, J. A. (1994a). Enzyme-resistant starch. IV. Effect of endogenous lipids and added sodium dodecyl sulfate on formation of resistant starch. Cereal Chemistry 71, 170-177.

Eerlingen, R. C., Crombez, M. \& Delcour, J. A. (1993 a). Enzyme-resistant starch. I. Quantitative and qualitative influence of incubation time and temperature of autoclaved starch on resistant starch formation. Cereal Chemistry 70, 339-344.

Eerlingen, R. C., Deceuninck, M. \& Delcour, J. A. (1993b). Enzyme-resistant starch. II. Influence of amylose chain length on resistant starch formation. Cereal Chemistry 70, 345-350.

Eerlingen, R. C. \& Delcour, J. A. (1995). Formation, analysis, structure and properties of type III enzyme resistant starch. Journal of Cereal Science 22, 129-138.

Eerlingen, R. C., Jacobs, H. \& Delcour, J. A. (1994b). Enzyme-resistant starch. V. The impact of retrogradation of waxy maize starch on enzyme susceptibility. Cereal Chemistry 71, 351-355. 
Eerlingen, R. C., Van den Broeck, I., Delcour, J. A., Slade, L. \& Levine, H. (1994c). Enzyme-resistant starch. VI. Influence of sugars on resistant starch formation. Cereal Chemistry 71, 472-476.

Eerlingen, R. C., Van Haesendonck, I. P., De Paepe, G. \& Delcour, J. A. (1994 $d$ ). Enzyme-resistant starch. III. The quality of straight dough breads containing varying levels of enzyme-resistant starch. Cereal Chemistry 71 , $165-170$.

Eggum, B. O. (1973). A study of certain factors influencing protein utilization in rats and pigs. Report 406. Copenhagen: National Institute of Animal Science.

Ekwall, H., Björck, I. \& Asp, N.-G. (1995). Evaluation of RS content in an animal model based on antibiotictreated rats. In Asp et al. (1995), pp. 105-107.

Ekwall, H., Langkilde, A. M., Asp, N.-G., Björck, I. \& Andersson, H. (1995). Digestibility of starch - amount and composition of resistant starch recovered in vivo from ileostomists and in vitro. Scandinavian Journal of Nutrition 39, $145-150$

Ellegård, L.\& Bosaeus, J. (1991). Sterol and nutrient excretion in ileostomists on prudent diets. European Journal of Clinical Nutrition 45, 451-457.

Englyst, H. N. \& Cummings, J. H. (1985). Digestion of the polysaccharides of some cereal foods in the human small intestine. American Journal of Clinical Nutrition 42,778-787.

Englyst, H. N. \& Cummings, J. H. (1986). Digestion of the carbohydrates of banana (Musa paradisiaca sapientum) in the human small intestine. American Journal of Clinical Nutrition 44, 42-50.

Englyst, H. N. \& Cummings, J. H. (1987). Digestion of polysaccharides of potato in the small intestine of man. American Journal of Clinical Nutrition 45, 423-431.

Englyst, H. N. \& Cummings, J. H. (1990). Dietary fibre and starch : definition, classification and measurement. In Dietary Fibre Perspectives: Reviews and Bibliography, pp. 3-26 [A. R. Leeds, editor]. London: John Libbey.

Englyst, H. N., Hay, S. \& Macfarlane, G. T. (1987). Polysaccharide breakdown by mixed populations of human faecal bacteria. FEMS Microbiology Ecology 95, 163-171.

Englyst, H. N. \& Kingman, S. M. (1990). Dietary fibre and resistant starch. A nutritional classification of plant polysaccharides. In Dietary Fiber, pp. 49-65. [D. Kritchevsky, C. Bonfield and J. W. Anderson, editors]. New York: Plenum Press.

Englyst, H. N., Kingman, S. M. \& Cummings, J. H. (1992). Classification and measurement of nutritionally important starch fractions. European Journal of Clinical Nutrition 46, Supplement 2, S33-S50.

Englyst, H. N. \& Macfarlane, G. T. (1986). Breakdown of resistant and readily digestible starch by human gut bacteria. Journal of the Science of Food and Agriculture 37, 699-706.

Englyst, H. N., Wiggins, H. S. \& Cummings, J. H. (1982). Determination of the non-starch polysaccharides in plant foods by gas-liquid chromatography of constituent sugars as alditol acetates. Analyst 107, 307-318.

Escarpa, A., Gonzalez, M. C., Mañas, E., García-Diz, L. \& Saura-Calixto, F. (1996). Resistant starch formation: standardization of a high-pressure autoclave process. Journal of Agricultural and Food Chemistry, in press.

Faisant, N. (1994). [Resistant Starches, Structural Analyses of Undigested Starch at the End of the Small Intestine in Man and Physiological Effects.] Doctoral thesis, University of Paris.

Faisant, N., Buléon, A., Colonna, P., Molis, C., Lartigue, S., Galmiche, J. P. \& Champ, M. (1995a). Digestion of raw banana starch in the small intestine of healthy humans: structural features of resistant starch. British Journal of Nutrition 73, $111-123$.

Faisant, N., Champ, M., Colonna, P. \& Buléon, A. (1993a). Structural discrepancies in resistant starch obtained in vivo in humans and in vitro. Carbohydrate Polymers 21, 205-209.

Faisant, N., Champ, M., Colonna, P. \& Buléon, A. (1993b). Structural features of starch that escapes digestion in the human small intestine. In Bioavailability '93. Proceedings of the Conference on Nutritional, Chemical and Food Processing Implications of Nutrient Availability, pp. 146-150.

Faisant, N., Champ, M., Colonna, P., Buléon, A., Molis, C., Langkilde, A. M., Schweizer, T., Flourié, B. \& Galmiche, J. P. (1993c). Structural features of resistant starch at the end of the human small intestine. European Journal of Clinical Nutrition 47, 285-296.

Faisant, N., Champ, M., Molis, C. \& Galmiche, J.-P. (1992). The use of solid phase markers for the intubation technique in humans. In Methodological Aspects of In Vivo Methods for Measurement of Starch Digestibility. EURESTA Report, pp. 25-28 [E. Gudmand-Høyer, editor]. Denmark: Vedbak.

Faisant, N., Champ, M., Ranganathan, S., Azoulay, C., Kergueris, M. F. \& Krempf, M. (1994). Effects of resistant starch supplementation on postprandial metabolism in healthy subjects. Reproduction, Nutrition, Development 34, 617-618 (abstract).

Faisant, N., Colonna, P., Buléon, A., Bouchet, B., Gallant, D. \& Champ, M. (1995 b). Characteristics of starches escaping human small intestine digestion/absorption. In Asp et al. (1995), pp. 115-116.

Faisant, N., Gallant, D. J., Bouchet, B. \& Champ, M. (1995c). Banana starch breakdown in the human small intestine studied by electronic microscopy. European Journal of Clinical Nutrition 49, 98-104.

Faisant, N., Planchot, F., Kozlowski, F., Pacouret, M.-P., Colonna, P. \& Champ, M. (1995d). Resistant starch determination adapted to products containing high level of resistant starch. Sciences des Aliments 15, 83-89.

Faulks, R. M., Southon, S. \& Livesey, G. (1989). Utilization of $\alpha$-amylase (EC 3.2.1.1) resistant maize and pea (Pisum sativum) starch in the rat. British Journal of Nutrition 61, 291-300.

Finegold, S. M., Sutter, V. L., Boyle, J. D. \& Shimada, K. (1970). The normal fiora of ileostomy and transverse colostomy effluents. Journal of Infectious Diseases 122, 376-381. 
Flourié, B. (1992). Intubation studies. In Methodological Aspects of In Vivo Methods for Measurement of Starch Digestibility. EURESTA Report, pp. 23-24 [E. Gudmand-Høyer, editor]. Vedbæk.

Flourié, B., Florent, C., Jouany, J.-P., Thivend, P., Etanchaud, F. \& Rambaud, J.-C. (1986). Colonic metabolism of wheat starch in healthy humans. Effects on fecal outputs and clinical symptoms. Gastroenterology $\mathbf{9 0}$, 111-119.

Flourié, B., Leblond, A., Florent, C., Rantureau, M., Bisalli, A. \& Rambaud, J.-C. (1988). Starch malabsorption and breath gas excretion in healthy humans consuming low- and high-starch diets. Gastroenterology 95. $356-363$.

Gallant, D. J. \& Bouchet, B. (1986). Ultrastructure of the maize starch granules. Journal of Food Microstructure $5,141-155$

Gạllant, D. J., Bouchet, B., Buléon, A. \& Pérez, S. (1992). Physical characteristics of starch granules and susceptibility to enzymatic degradation. European Journal of Clinical Nutrition 46, Supplement 2, S3-S16.

Gee, J. M., Faulks, R. M. \& Johnson, I. T. (1991). Physiological effects of retrograded $\alpha$-amylase-resistant cornstarch in rats. Journal of Nutrition 121, $44-49$.

Gee, J. M., Faulks, R. M., Mathers, J. C. \& Edwards, C. A. (1995). Effects of resistant starch on intestinal structure and function - an animal model. In Asp et al. (1995), pp. 33-37.

Gibson, G. R., Cummings, J. H., Macfarlane, G. T., Allison, C., Segal, I., Vorster, H. H. \& Walker, A. R. P. (1990). Alternative pathways for hydrogen disposal during fermentation in the human colon. Gut 31, 679-683.

Goñi, I., Mañas, E., García-Diz, L. \& Saura-Calixto, F. (1996). Analysis of resistant starch : a method for foods and food products. Food Chemistry, in press.

Goodlad, J. S. \& Mathers, J. C. (1992). Digestion of complex carbohydrates and large bowel fermentation in rats fed on raw and cooked peas (Pisum sativum). British Journal of Nutrition 67, 475-488.

Granfeldt, Y. E., Drews, A. W. \& Björck, I. M. E. (1993). Starch bioavailability in arepas made from ordinary or high amylose corn: concentration and gastrointestinal fate of resistant starch in rats. Journal of Nutrition 123 , $1676-1684$.

Granfeldt, Y., Drews, A. \& Björck, 1. (1995). Arepas made from high amylose corn flour produce favorably low glucose and insulin responses in healthy subjects. Journal of Nutrition 125, 459-465.

Hansen, H. B., Østergaard, K. \& Bach Knudsen, K. E. (1988). Effect of baking and staling on carbohydrate composition in rye bread and on digestibility of starch and dietary fibre in vivo. Journal of Cereal Science 7 , $135-144$.

Hansen, I. (1989). Dietary Fibre: Chemical and Physical Characteristics and Effects on Digestibility of Nutrients and Energy Metabolism in the Rat. PhD thesis. Copenhagen: Royal Veterinary and Agricultural University.

Heijnen, M.-L. A., Deurenberg, P., Van Amelsvoort, J. M. M. \& Beynen, A. C. (1995a). The effect of resistant starch types II and III on the absorption of calcium, magnesium and phosphorus in healthy men. In Asp et al. (1995), pp. $120-121$.

Heijnen, M.-L. A., Deurenberg, P., Van Amelsvoort, J. M. M. \& Beynen, A. C. (1995b). Replacement of digestible by resistant starch lowers diet-induced thermogenesis in healthy men. British Journal of Nutrition 73 , $423-432$.

Heijnen, M.-L. A., Van Amelsvoort, J. M. M., Deurenberg, P. \& Beynen, A. C. (1996). Neither raw nor retrograded starch lowers fasting serum cholesterol levels in healthy, normolipidemic subjects. American Journal of Clinical Nutrition (in press).

Hildebrandt, L. A. \& Marlett, J.A. (1991). Starch bioavailability in the upper gastrointestinal tract of colectomized rats. Journal of Nutrition 121, 679-686.

Holm, J., Björck, I., Ostrowska, S., Eliasson, A.-C., Asp, N.-G., Larsson, K. \& Lundquist, I. (1983). Digestibility of amylose/lipid complexes in vitro and in vivo. Starch 35, 294297.

Imberty, A., Chanzy, H, Pérez, S., Buléon, A. \& Tran, V. (1988). The double-helical nature of the crystalline part of A-starch. Journal of Molecular Biology 201, 365-378.

Imberty, A. \& Pérez, S. (1988). A revisit to the threc-dimensional structure of B-type starch. Biopolymers 27, $1205-1221$.

Johansson, C.-G., Siljeström, M. \& Asp, N.-G. (1984). Dietary fibre in bread and corresponding flours - formation of resistant starch during baking. Zeitschrift für Lebensmittel-Untersuchung und-Forschung 179, $24-28$.

Key, F. B. \& Mathers, J. C. (1993). Complex carbohydrates digestion and large bowel fermentation in rats given wholemeal bread and cooked haricot beans (Phaseolus vulgaris) fed in mixed diets. British Journal of Nutrition 69, 497-509.

Langkilde, A. M. \& Andersson. H. (1992). Nutrients and sterols excreted in ileostomy effluents after a diet with autoclaved amylomaize or ordinary corn starch. European Journal of Clinical Nutrition 46, Supplement 2, S127.

Langkilde, A. M. \& Andersson, H. (1995a). Excretion of starch, other nutrients and sterols from the small bowel - an ileostomy study. In Asp et al. (1995), pp. 126-127.

Langkilde, A. M. \& Andersson, H. (1995b). In vivo quantification of resistant starch in EURESTA reference materials using the ileostomy model. In Asp et al. (1995), pp. 31--32.

Langkilde, A. M., Andersson, H., Faisant, N. \& Champ, M. (1995). A comparison between the intubation technique and the ileostomy model for in vivo measurement of RS. In Asp et al. (1995), pp. 28-30.

Leloup, V. M.. Colonna, P. \& Ring, S. G. (1992). Physicochemical aspects of resistant starch. Journal of Cereal Science 16, 253-266. 
Levitt, M. D., Hirsh, P., Fetzer, C. A., Sheahan, M. \& Levine, A. S. (1987). H $_{2}$ excretion after ingestion of complex carbohydrates. Gastroenterology 92, 383-389.

Liljeberg, H. \& Björck, I. (1994). Bioavailability of starch in bread products. Postprandial responses in healthy subjects and in vitro resistant starch content. European Journal of Clinical Nutrition 48, 151-163.

Liljeberg, H., Granfeldt, Y. \& Björck, I. (1995). RS content in relation to rate of starch hydrolysis and glycaemic response. In Asp et al. (1995), pp. 128-132.

Livesey, G. (1992). The energy values of dietary fibre and sugar alcohols for man. Nutrition Research Reviews $\mathbf{5}$, 61-84.

Livesey, G. (1995). EURESTA Working Group IV; Energy value of resistant starch. In Asp et al. (1995), pp. 56-62.

Livesey, G., Davies, I. R., Brown, J. C., Faulks, R. M. \& Southon, S. (1990). Energy balance and energy values of $\alpha$-amylase (EC 3.2.1.1)-resistant maize and pea (Pisum sativum) in the rat. British Journal of Nutrition 63, $467-480$.

Livesey, G., Johnson, I. T., Gee, J. M., Smith, T., Lee, W., Hillan, K. A., Mayer, J. \& Turner, S. C. (1993). 'Determination' of sugar alcohol and polydextrose absorption in humans by the breath hydrogen $\left(\mathrm{H}_{2}\right)$ technique: the stoichiometry of hydrogen production and the interaction between carbohydrates assessed in vivo and in vitro. European Journal of Clinical Nutrition 47, 419430.

Macfarlane, G. T. \& Englyst, H. N. (1986). Starch utilization by the human large intestinal microflora. Journal of Applied Bacteriology 60, 195-201.

Mathé, D., Riottot, M., Rostaqui, N., Sacquet, E., Navarro, N., Lécuyer, B. \& Lutton, C. (1993). Effect of amylomaize starch on plasma lipoproteins of lean and obese Zucker rats. Journal of Clinical Biochemistry and Nutrition 14, 17-24.

Mathers, J. C., Carter, S., Smith, H. \& Reds, K. A. (1995). Physiological responses to raw potato starch ingestion by the rat. In Asp et al. (1995), p. 133.

Mathers, J. C. \& Dawson, L. D. (1991). Large bowel fermentation in rats eating processed potatoes. British Journal of Nutrition 66, 313-329.

Mathers, J. C. \& Smith, H. (1993). Factors influencing caecal butyrate in rats fed raw potato starch. Proceedings of the Nutrition Society 52, 376A.

Molis, C., Champ, M., Flourié, B., Pellier, P., Bornet, F., Colonna, P., Kozlowski, F., Rambaud, J.-C. \& Galmiche, J. P. (1992). Small intestinal digestibility of processed corn starches in healthy human subjects. Luropean Journal of Clinical Nutrition 46, Supplement 2, S131-S132.

Mcrand, C., Levrat, M. A., Besson, C., Demigné, C. \& Rémésy, C. (1994). Effects of a diet rich in resistant starch on hepatic lipid metabolism in the rat. Journal of Nutritional Biochemistry 5, 138-144.

Muir, J. G., Birkett, A., Brown, I., Jones, G. \& O’Dea, K. (1995). Food processing and maize variety affects amounts of starch escaping digestion in the small intestine. American Journal of Clinical Nutrition 61, 82-89,

Muir, J. G. \& O'Dea, K. (1992). Measurement of resistant starch: factors affecting the amount of starch escaping digestion in vitro. American Journal of Clinical Nutrition 56, 123-127.

Muir, J. G. \& O'Dea, K. (1993). Validation of an in vitro assay for predicting the amount of starch that escapes digestion in the small intestine of humans. American Journal of Clinical Nutrition 57, 540-546.

Noah, L., Guillon, F., Bouchet, B., Buléon, A., Gallant, D. J., Colonna, P., Molis, C., Faisant, N., Galmiche, J. P. \& Champ, M. (1995). Digestion of carbohydrate components of dry beans (Phaseolus vulgaris) in healthy humans. Proceedings of the AEP conference 'Improving Production \& Utilisation of Grain Legumes', Copenhagen, pp. 276-277.

Olesen, M. \& Gudmand-Høyer, E. (1995). Hydrogen and methane breath test in evaluation of resistant starch. in Asp et al. (1995), pp. 22-24.

Olesen, M., Rumessen, J. J. \& Gudmand-Høyer, E. (1994). Intestinal transport and fermentation of resistant siarch evaluated by the $\mathrm{H}_{2}$ breath test. European Journal of Clinical Nutrition 48, 692-701.

Olesen, M., Rumessen, J. J. \& Gudmand-Høyer, E. (1995). Resistant starch has no measurable influence on gastric emptying, or on blood-cholesterol. In Asp et al. (1995), p. 144.

Rabe, E. \& Sievert, D. (1992). Effects of baking, pasta production, and extrusion cooking on formation of resistant starch. European Journal of Clinical Nutrition 46, Supplement 2, S105-S107.

Raben, A., Christensen, N. J., Madsen, J., Holst, J. J. \& Astrup, A. (1994a). Decreased postprandial thermogenesis and fat oxidation but increased fullness after a high-fiber meal compared with a low-fiber meal. American Journal of Clinical Nutrition 59, 1386-1394.

Raben, A., Tagliabue, A., Christensen, N. J., Madsen, J., Holst, J. J. \& Astrup, A. (1994b). Resistant starch: the effect on postprandial glycemia, hormonal response and satiety. American Journal of Clinical Nutrition 60 , $544-551$.

Ranganathan, S., Champ, M., Pechard, C., Blanchard, P., N'Guyen, M., Colonna, P. \& Krempf, M. (1994). Comparative study of the acute effects of resistant starch and dietary fibers on metabolic indexes in men. American Journal of Clinical Nutrition 59, 879-883.

Read, N. W., Al Janabi, M. N., Bates, T. E. \& Barber, D. C. (1983). Effect of gastrointestinal intubation on the passage of a solid meal through the stomach and small intestine in humans. Gastroenterology 84, $1568-1572$.

Rumessen, J. J. (1992). Hydrogen and methane breath tests for evaluation of resistant carbohydrates. European Journal of Clinical Nutrition 46, Supplement 2, S77-S90. 
Sacquet, E., Leprince, C. \& Riottot, M. (1983). Effect of amylomaize starch on cholesterol and bile acid metabolism in germfree (axenic) and conventional (holoxenic) rats. Reproduction, Nutrition, Développement 23, 783-792.

Saura-Calixto, F., Goñi, I., Bravo, L. \& Mañas, E. (1993). Resistant starch in foods: modified method for dietary fibre residues. Journal of Food Science 58, 642-643.

Scheppach, W., Fabian, C., Sachs, M. \& Kasper, H. (1988). The effect of starch malabsorption on fecal short chain fatty acid excretion in man. Scandinavian Journal of Gastroenterology 23, 755-759.

Schulz, A. G. M., Van Amelsvoort, J. M. M. \& Beynen, A. C. (1993). Dietary native resistant starch but not retrograded resistant starch raises magnesium and calcium absorption in rats. Journal of Nutrition 123, 1724-1731.

Schweizer, T. F., Andersson, H., Langkilde, A. M., Reimann, S. \& Torsdottir, I. (1990). Nutrients excreted in ileostomy effluents after consumption of mixed diets with beans or potatoes. II. Starch, dietary fibre and sugars. European Journal of Clinical Nutrition 44, 567-575.

Shetty, P. S. \& Kurpad, A. V. (1986). Increasing starch intake in the human diet increases fecal bulking. American Journal of Clinical Nutrition 43, 210-212.

Sievert, D. \& Würsch, P. (1993a). Amylose chain association based on differential scanning calorimetry. Journal of Fond Science 58, 1332-1334.

Sievert, D. \& Würsch, P. (1993b). Thermal behavior of potato amylose and enzyme-resistant starch from maize. Cereal Chemistry 70, 333-338.

Stephen, A. M. (1991). Starch and dietary fibre: their physiological and epidemiological interrelationships. Canadian Journal of Physiology and Pharmacology 69, 116-120.

Tagliabue, A., Raben, A., Heijnen, M.-L., Deurenberg, P., Pasquali, E. \& Astrup, A. (1995a). The effect of raw potato starch on energy expenditure and substrate oxidation. American Journal of Clinical Nutrition 61, 1070-1075.

Tagliabue, A., Raben, A., Heijnen, M.-L., Deurenberg, P., Pasquali, E. \& Astrup, A. (1995b). Resistant starch and postprandial energy expenditure. In Asp et al. (1995), pp. 166-168.

Tappy, L., Würsch, P., Randin, J. P., Felber, J. P. \& Jéquier, E. (1986). Metabolic effect of pre-cooked instant preparations of bean and potato in normal and in diabetic subjects. American Journal of Clinical Nutrition 43, 30-36.

Tomlin, J. \& Read, N. W. (1990). The effect of resistant starch on colon function in humans. British Journal of Nutrition 64, 589-595.

Tovar, J., Björck, I. M. \& Asp, N.-G. (1990). Starch content and $\alpha$-amylolysis rate in precooked legume flours. Journal of Agricultural and Food Chemistry 38, 1818-1823.

Tovar, J., Björck, I. M. \& Asp, N.-G. (1992). Incomplete digestion of legume starches in rats: a study of precooked flours containing retrograded and physically inaccessible starch fractions. Journal of Nutrition $\mathbf{1 2 2}$, 1500-1507.

Van der Westhuizen, J., Mbizvo, M. \& Jones, J. J. (1972). Unrefined carbohydrate and glucose tolerance. Lancet ii, 719 .

Van Munster, I. P., Nagengast, F. M., Jansen, M., De Boer, H., De Haan, T. \& Katan, M. B. (1995). In-vitro inhibition of cholate conversion and decrease of soluble deoxycholate by lactulose and resistant starch. In Asp et al. 1995), pp. 171-174.

Van Munster, I. P., Tangerman, A. \& Nagengast, F. M. (1994). The effect of resistant starch on colonic fermentation, bile acid metabolism, and mucosal proliferation. Digestive Diseases and Sciences 39, 834-842.

Verbeek, M. J. F., De Deckere, E. A. M., Tijburg, L. B. M., Van Amelsvoort, J. M. M. \& Beynen, A. C. (1995). Influence of dietary retrograded starch on the metabolism of neutral steroids and bile acids in rats. British Journal of Nutrition 74, 807-820.

Wolf, M. J., Khoo, U. \& Inglett, G. E. (1977). Partial digestibility of cooked amylomaize starch in humans and mice. Stärke 12, 401-405.

Würsch, P. \& Delcour, J. (1995). EURESTA Working Group II : Technology of resistant starch production. In Asp et al. (1995), pp. 15-19.

Wyatt, G. M. \& Horn, N. (1988). Fermentation of resistant food starches by human and rat intestinal bacteria. Journal of the Science of Food and Agriculture 44, 281-288. 